OPEN ACCESS

Edited by: Annemarie Van Rossum,

Erasmus University Medical Center-Sophia Children's Hospital,

Netherlands

Reviewed by:

Marta Palusinska-Szysz,

Maria Curie-Sklodowska University,

Poland

Tsuyoshi Kenri,

National Institute of Infectious

Diseases, Japan

*Correspondence:

Gretchen L. Parrott

groseler1@gmail.com

Specialty section

This article was submitted to Infectious Diseases,

a section of the journal

Frontiers in Microbiology

Received: 04 December 2015

Accepted: 29 March 2016

Published: 12 April 2016

Citation:

Parrott GL, Kinjo T and Fujita J (2016)

A Compendium for Mycoplasma pneumoniae. Front. Microbiol. 7:513.

doi: 10.3389/fmicb.2016.00513

\section{A Compendium for Mycoplasma pneumoniae}

\author{
Gretchen L. Parrott*, Takeshi Kinjo and Jiro Fujita
}

Department of Infectious Diseases, Respiratory and Digestive Medicine, Graduate School of Medicine, University of the Ryukyus, Nishihara, Japan

Historically, atypical pneumonia was a term used to describe an unusual presentation of pneumonia. Currently, it is used to describe the multitude of symptoms juxtaposing the classic symptoms found in cases of pneumococcal pneumonia. Specifically, atypical pneumonia is a syndrome resulting from a relatively common group of pathogens including Chlamydophila sp., and Mycoplasma pneumoniae. The incidence of $M$. pneumoniae pneumonia in adults is less than the burden experienced by children. Transmission rates among families indicate children may act as a reservoir and maintain contagiousness over a long period of time ranging from months to years. In adults, M. pneumoniae typically produces a mild, "walking" pneumonia and is considered to be one of the causes of persistent cough in patients. M. pneumoniae has also been shown to trigger the exacerbation of other lung diseases. It has been repeatedly detected in patients with bronchitis, asthma, chronic obstructive pulmonary disorder, and cystic fibrosis. Recent advances in technology allow for the rapid diagnosis of M. pneumoniae through the use of polymerase chain reaction or rapid antigen tests. With this, more effort has been afforded to identify the causative etiologic agent in all cases of pneumonia. However, previous practices, including the overprescribing of macrolide treatment in China and Japan, have created increased incidence of macrolide-resistant $M$. pneumoniae. Reports from these countries indicate that $>85 \%$ of $M$. pneumoniae pneumonia pediatric cases are macrolide-resistant. Despite its extensively studied past, the smallest bacterial species still inspires some of the largest questions. The developments in microbiology, diagnostic features and techniques, epidemiology, treatment and vaccines, and upper respiratory conditions associated with M. pneumoniae in adult populations are included within this review.

Keywords: Mycoplasma pneumoniae, pneumonia, atypical pneumonia, community-acquired pneumonia, walking pneumonia, CARDS toxin

\section{INTRODUCTION}

Mycoplasma pneumoniae, was first discovered in Eaton et al. (1944). It was originally known as the Eaton agent. The tiny pathogenic agent could pass through a sterile filter, but could not be grown on standard bacteriologic media. Thus, during that time, it was originally thought to be a virus. Volunteer and field studies during the 1950s and early 1960s provided evidence verifying the Eaton agent was a cause of lower respiratory tract infections in humans (Chanock et al., 1960, 1961; Mufson et al., 1961). Chanock et al. (1962) was able to culture the Eaton agent on a cell-free 
medium and proposed both the taxonomic designation as well as the name of the organism as we know it today.

Currently, as one of the most studied mycoplasmas, a large collective knowledge on $M$. pneumoniae has accumulated. Recent discoveries in microbiology and improvements in diagnostic techniques and treatments have led to dramatic advances. At the same time knowledge regarding M. pneumoniae epidemiology, associated upper respiratory conditions, and vaccine candidates has also expanded. These topics and how they affect adult populations will be briefly covered in this review.

\section{MICROBIOLOGY}

With a small cell size and volume, just 1-2 $\mu \mathrm{m}$ long and 0.1$0.2 \mu \mathrm{m}$ wide, mycoplasmas cannot individually be detected by light microscopy (Waites and Talkington, 2004) and colonies rarely exceed $100 \mu \mathrm{m}$ in diameter. Sequenced in Himmelreich et al. (1996), the genome of M. pneumoniae was shown to consist of only $816,394 \mathrm{bp}$ and 687 genes. Because of this small genome, the organism is limited in its capabilities and unable to synthesize rigid peptidoglycan cell walls. Alternatively, sterols provide the structural support in the triple-layer cell membrane. As a result, these organisms are insensitive to $\beta$-lactam antimicrobial agents, pleomorphic, and are unaffected by the gram staining method.

Mycoplasma pneumoniae reproduces via binary fission with well-organized chromosome segregation. Preceding binary cell fission, the attachment organelle, a specialized cellular structure that is responsible for cytadherence of this bacterium, duplicates (Krause and Balish, 2004; Balish, 2006; Balish and Krause, 2006). The resulting daughter organelle will migrate to the opposite pole of the cell before the completion of chromosomal separation. After duplication of chromosomal and cellular material, the now polar opposite attachment organelles will simultaneously bind to a surface and initiate gliding motility, pulling away from the central point; thus, creating daughter cells (Bredt, 1968; Miyata and Ogaki, 2006).

The attachment organelle is also crucial for host cellular interactions. Cytoskeletal proteins found within and around the attachment organelle facilitate adherence and motility. Of note, $\mathrm{P} 1$ and supporting proteins $\mathrm{P} 30, \mathrm{P} 90$, and $\mathrm{P} 40$ promote adhesion and binding to host cells via sialic acid receptors (Krivan et al., 1989; Roberts et al., 1989; Razin and Jacobs, 1992; Seto and Miyata, 2003; Waldo and Krause, 2006; Chaudhry et al., 2007), while P1, P30, P41, and P200 promote and regulate gliding motility (Kenri et al., 2004; Krause and Balish, 2004; Seto et al., 2005; Hasselbring and Krause, 2007; Jordan et al., 2007). Many authors allude to a cellular construction based on electron micrograph observations of cryosections (Hegermann et al., 2002; Henderson and Jensen, 2006; Seybert et al., 2006; Nakane et al., 2015). Integration and interpretation of these studies propose that the attachment organelle is connected to a rod consisting of two paired plates (rods), one thick and one thin, which is attached, at the proximal end, to a wheel-like protein complex (bowl-complex), the wheel (bowl) further connects to other cytoskeleton filaments in the peripheral cell. A schematic, assembled from literature interpretation, is depicted in Figure 1 (Meng and Pfister, 1980; Razin et al., 1998; Trachtenberg, 1998; Krause and Balish, 2001, 2004; Hegermann et al., 2002; Henderson and Jensen, 2006; Miyata and Ogaki, 2006; Seybert et al., 2006; Nakane et al., 2015). However, the exact mechanism by which the attachment organelle and associated structures and proteins initiate motility is still relatively unknown, although numerous authors support inchworm-like movement (Henderson and Jensen, 2006; Hatchel and Balish, 2008; Nakane et al., 2015).

Mycoplasma pneumoniae has not been found freely living in nature. It is predominantly considered a mucosal pathogen existing parasitically on the epithelial surface of its host. Interactions between $M$. pneumoniae and host tissue, continuously show the attachment organelle bound to the host cell surface (Wilson and Collier, 1976; Razin and Jacobs, 1992; Rottem, 2003). However, reports of internalization by lung epithelial cells also exist (Yavlovich et al., 2004). It is assumed cytadherence protects mycoplasma from clearance via the mucociliary apparatus and this attachment is ultimately considered the initiating event of disease.

\section{PATHOGENESIS}

Once bound to host tissue, pathogenic processes begin to occur. Hydrogen peroxide and superoxide, produced by M. pneumoniae through the metabolism of glycerol, have been shown to cause injury to epithelial cells and their associated cilia (Somerson et al., 1965; Low, 1971; Tryon and Baseman, 1987; Minion and Jarvill-Taylor, 1994). The effects of hydrogen peroxide on host cells such as erythrocytes include denaturation of hemoglobin,

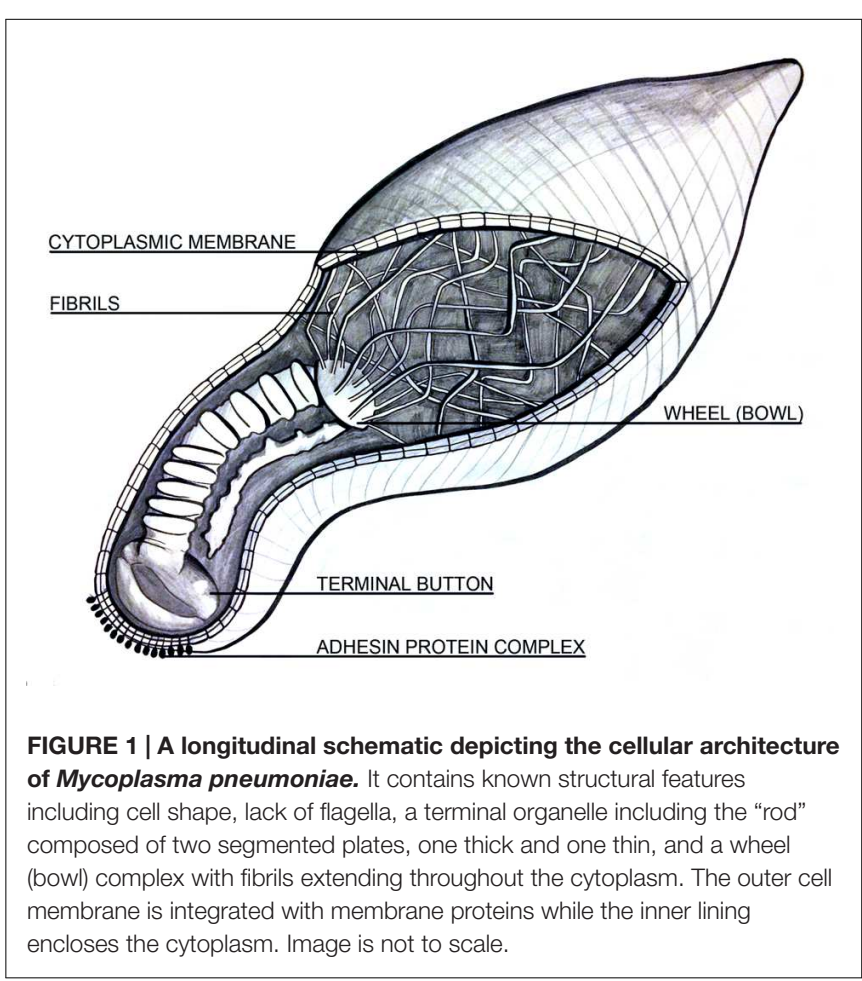


peroxidation of lipids, and eventual cell lysis. The same oxidative stress in the respiratory epithelium can result in both structural and functional deterioration of cilia (Waites and Talkington, 2004).

Recently discovered, the community-acquired respiratory distress syndrome (CARDS) toxin has also been shown to facilitate localized disruption and cytotoxicity (Kannan et al., 2005, 2010; Kannan and Baseman, 2006; Johnson et al., 2011; Becker et al., 2015). Cells exposed to this $68-\mathrm{kDa}$ proteinaceous toxin, with homologies to the pertussis toxin, exhibited distinct vacuolization and cell rounding (Kannan and Baseman, 2006). Other cellular effects of CARDS could include the loss of cilia, reduced oxygen consumption, glucose utilization, and amino acid uptake, as well as detachment and ultimate shedding of the infected cells, documented elsewhere (Clyde, 1971, 1983; Collier, 1983; Johnson et al., 2011). The dry, hacking cough commonly associated with early infection, is most likely the clinical manifestation of the aforementioned cellular damages endured by the upper respiratory tract (Waites and Talkington, 2004).

The CARDS toxin has also been shown to activate its own pathogenic response in animal models. A direct relationship between the number of $M$. pneumoniae organisms, amounts of the CARDS toxin, and severity of lung histopathology was observed in murine models (Techasaensiri et al., 2010; Kannan et al., 2011). Moreover, mice and baboons, which received recombinant CARDS toxin alone, elicited cellular inflammation similar to M. pneumoniae infection. This suggests the CARDS toxin, plays a major role in pathogenesis (Hardy et al., 2009).

Further, research has shown the CARDS toxin can localize with the NOD-like receptor containing pyrin domain 3 (NLRP3) inflammasome and catalyze the ADP-ribosylation of NLRP3 (Bose et al., 2014). As a result, the CARDS toxin is the first example of a toxin exhibiting both ADP-ribosylating and vacuolating properties (Krueger and Barbieri, 1995; Kannan and Baseman, 2006). In Figure 2, we propose a potential cell signaling model based on information collected from previously published reports (Fan et al., 2003; Yang et al., 2004; Chu et al., 2005; Xiang and Fan, 2010; Johnson et al., 2011; Kannan et al., 2011; Franchi and Nunez, 2012; Franchi et al., 2012; Bose et al., 2014; Saraya et al., 2014; Shimizu et al., 2014; Vanaja et al., 2015).

Interaction between respiratory epithelial cells and surface lipoproteins of $M$. pneumoniae is likely to induce the host immune system via Toll-like receptor (TLR)-2 (Chu et al,, 2005; Kraft et al., 2008) or TLR-4 (Shimizu et al., 2014) stimulating the synthesis of intracellular adhesion molecule (ICAM) receptors. Stimulation and crosstalk of the TLRs can trigger and amplify the production of chemokines promoting lymphocyte and neutrophil trafficking and inflammation in the lung (Fan et al., 2003; Yang et al., 2004; Saraya et al., 2011). In addition to respiratory epithelial cells, $M$. pneumoniae has been shown to directly activate and induce the production of cytokines from unsorted peripheral blood leukocytes (Kita et al., 1992), lymphocytes (Simecka et al., 1993; Medina et al., 2012), and monocytes and macrophages (Yang et al., 2003; Broaders et al., 2006). Opsonization may also occur but the evidence is minimal since re-infection is common.
Macrophages, including alveolar macrophages likely play a central role as an innate immune defense mechanism through phagocytosis. Alveolar macrophages, in particular, can also secrete pro-inflammatory cytokines, such as RANTES, which is a known chemo-attractant for neutrophils and basophils (Bischoff et al., 1993; Saraya et al., 2011; Tani et al., 2011). According to some reports, the most distinguishing pathological feature resulting from this organism in human pneumonia is an increase of plasma cell-rich lymphocytic infiltration in the peri-bronchovascular areas (PBVAs), with accumulation of macrophages, neutrophils, and lymphocytes in alveolar spaces (Coultas et al., 1986; Hayashi et al., 1986; Rollins et al., 1986; Saraya et al., 2014).

The underlying cell-mediated immunity of the host also plays an important role in the progression and development of $M$. pneumoniae related diseases. Furthermore, cell-mediated immunity level or predominant response is potentially correlated to the variable pulmonary patterns seen in chest images (Tanaka et al., 1996; Saraya et al., 2011, 2014). Multiple studies have acknowledged the importance of IL-12, interferon- $\gamma$, and Th1 type T-cell responses during the course of $M$. pneumoniae infections (Fonseca-Aten et al., 2005; Tagliabue et al., 2008; Hardy et al., 2009; Techasaensiri et al., 2010). However, a recombinant CARDS toxin has resulted in potent allergic-type pulmonary inflammation characterized by T-cell dependence, airway hyperreactivity, and production of Th2 type cytokines (Medina et al., 2012). In sensitized mice, M. pneumoniae can lead to Th2 type T-cell allergic inflammation (Chu et al., 2003, 2005). While, other previous animal studies have shown the histopathological score of $M$. pneumoniae pneumonia is significantly higher in $\mathrm{BALB} / \mathrm{c}$ mice (Th2 predominant) than in C57BL/6 mice (Th1 predominant; Fonseca-Aten et al., 2005). The collective interpretation of all these findings suggest an attractive link to the differences observed in human host cell-mediated immunity response against the organism and the resulting variable pathogenic patterns seen in chest images and serological responses (Kraft et al., 1998; Nisar et al., 2007; Atkinson et al., 2009; Saraya et al., 2011).

\section{EPIDEMIOLOGY}

Mycoplasma pneumoniae is able to infect both the upper and lower respiratory tracts and it can create both endemic and epidemic situations among children and adults worldwide. From 2001 to 2006, M. pneumoniae was the most common atypical pathogen identified in 39 hospitals across 11 countries (Arnold et al., 2007). However, most available data regarding M. pneumoniae infections comes from studies performed in Japan, Europe, and the United States. Within Europe, $M$. pneumoniae is frequently included in regular surveillance, but studies from arctic and tropical zones point to the many diverse populations with infections due to this organism (Suhs and Feldman, 1966; Golubjatnikov et al., 1975; Joosting et al., 1976; Campos et al., 1993).

Mycoplasma pneumoniae has a diminutive size, which allows it to spread from person to person through droplet infection 


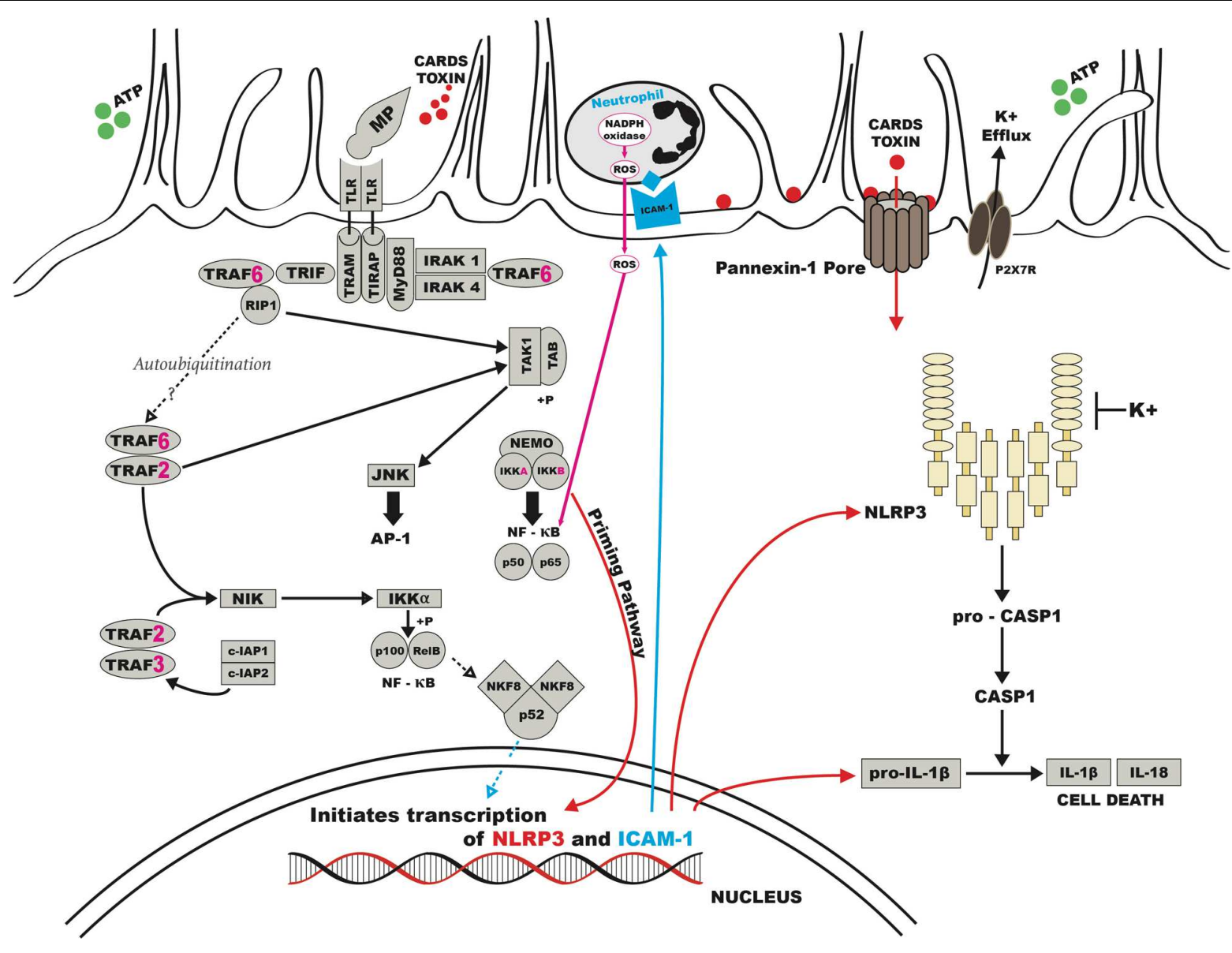

FIGURE 2 | Possible schematic for pathogenesis of human M. pneumoniae. CARDS, Community Acquired Respiratory Distress Syndrome; ATP, adenosine tri-phosphate; K, potassium; ICAM, intracellular adhesion molecule; NADPH, nicotinamide adenine dinucleotide phosphate; ROS, reactive oxygen species; TLR, toll like receptor.

during close contact. Following a coughing event, contaminated droplets disperse through the air. The eventual cytadherence by the bacteria in an alternate host describes successful transmission. Some patients may remain infectious for prolonged periods despite the disappearance of many symptoms, other than cough (Hallander et al., 1999; Wadowsky et al., 2002; Ishida et al., 2010; Wang et al., 2011).

Immunity is not long lasting; the bacteria and its associated disease can relapse in patients even after adherence to an effective antibiotic regimen (Watson and Storch, 2008). The genomic variation of the P1 adhesin may contribute to this complex and recurring epidemiology. There are two main subtypes of M. pneumoniae frequently isolated from clinical specimens ( $\mathrm{Su}$ et al., 1990), though other variants have been reported (DorigoZetsma et al., 2000; Dumke et al., 2010b; Pereyre et al., 2012). Japan has reported the cycling of prevalent subtypes. Between 1995 and 2001, subtype 2 was accountable for the majority of infections, but between 2002 and 2005, subtype 1 became more prevalent (Kenri et al., 2008). It is not yet understood if recurrence within one individual is caused by reactivated infection or exposure to different genetic subtypes.
Interestingly, epidemic and endemic settings also report a polyclonal spread of the bacteria (Chalker et al., 2011; Pereyre et al., 2012, 2013), with multiple types or strains propagating within the human population simultaneously. This observation indicates point source infection is not the probable cause of countrywide epidemics; rather, a more likely cause is some environmental factor. Rates of $M$. pneumoniae vary annually, yet cyclic epidemic patterns have been observed every three to five years in long-term studies and geographic surveillance (Lind et al., 1997; Nir-Paz et al., 2012). It has been suggested most epidemics occur in either late summer or autumn within North America (Alexander et al., 1966; Feikin et al., 1999). However, other geographic regions report maintained epidemics through all seasons (Foy et al., 1979; Blystad et al., 2012; Nir-Paz et al., 2012; Polkowska et al., 2012; Uldum et al., 2012). A recent study from Fukuoka, Japan has reported climactic events related to the El Niño Southern Oscillation and Indian Ocean Dipole were significantly associated with monthly incidence of $M$. pneumoniae in both 2005-2007 and 2010-2011 (Onozuka and Chaves, 2014). These weather events may be responsible for both the cyclic 3-5 years 
resurgence pattern as well as the differing seasonality across continents.

In adults, $M$. pneumoniae is potentially responsible for more than $35 \%$ of hospitalized community-acquired pneumonia (CAP) cases (Marston et al., 1997; Dey et al., 2000; Cunha and Pherez, 2009). However, a recent report from the Centers for Disease Control and Prevention, estimated only $2 \%$ of detectable pathogens in hospitalized CAP patients were due to M. pneumoniae (Jain et al., 2015). Moreover, a report from the Atypical Pathogens Reference Laboratory Database attributes $12 \%$ (range 11-15\%) of global CAP incidence to M. pneumoniae (Arnold et al., 2007). This last estimate does take into account the fluctuation of both seasonal and outbreak years, covering almost five winter seasons in its data analysis. However, patients with CAP typically have mild symptoms and are treated as outpatients, if at all. Therefore, the number of M. pneumoniae cases reported may be an underestimation of actual burden.

Prevalence, documented in other studies, can have a wide range Marston et al. (1997), reported 5.4\% of CAP in hospitalized adults in the United States was due to $M$. pneumoniae by serology. Also using serology in Porath et al. (1997), from Israel, reported $29.2 \%$ of hospitalized CAP adults were infected with M. pneumoniae. Wattanathum et al. (2003), Thailand reported similarly high rates by serology, with $29.6 \%$ of outpatients with symptoms due to $M$. pneumoniae. Whereas, von Baum et al. (2009), polymerase chain reaction (PCR) and serological analysis from Germany showed $6.8 \%$ of CAP cases were due to $M$. pneumoniae, of which $55 \%$ were treated as outpatients. Prevalence reporting for most countries, however, is difficult due to the non-availability of reliable, rapid diagnostic techniques and an organized reporting system (Kashyap and Sarkar, 2010).

We calculated an estimated number of $M$. pneumoniae cases per 100,000 people by linear interpolation based on in country reports collected during our review process (Bii et al., 2002; Chaoprasong et al., 2002; Accomando et al., 2004; Nagalingam et al., 2004; Obeidat et al., 2005; Matute et al., 2006; Petitjean Lecherbonnier et al., 2006; Shankar et al., 2006; Somer et al., 2006; Kung, 2007; Huang et al., 2008; Boettcher et al., 2010; Prodromidou et al., 2010; Touati et al., 2010; Eick et al., 2011; Song et al., 2011; Wang et al., 2011; Bajraktarevic et al., 2012; Blystad et al., 2012; Feikin et al., 2012; Hoffmann et al., 2012; Lenglet et al., 2012; Polkowska et al., 2012; Uldum et al., 2012; Wellinghausen et al., 2012; Chen et al., 2013, 2015; Hong et al., 2013; Kawai et al., 2013; Luchsinger et al., 2013; Wu et al., 2013; Carrim et al., 2014; Grassi et al., 2014; Moore et al., 2014; Neocleous et al., 2014; Zhao et al., 2014; Kogoj et al., 2015; Liu et al., 2015). The resulting data is shown in Figure 3, with elevated rates possibly found throughout China, Russia, Mexico, and Brazil.

The majority of outbreaks have occurred within a community or in closed or semi-closed settings such as military bases or universities (Mogabgab, 1968; Edwards et al., 1976; Gray et al., 1997, 1999; Feikin et al., 1999; Crum et al., 2005; Walter et al., 2008; Centers for Disease Control and Prevention [CDC], 2012, 2013; Waller et al., 2014), hospitals (Fischman et al., 1978; Kashiwagi et al., 1985; Kleemola and Jokinen, 1992; Hyde et al., 2001; Shangguan et al., 2014), and facilities for

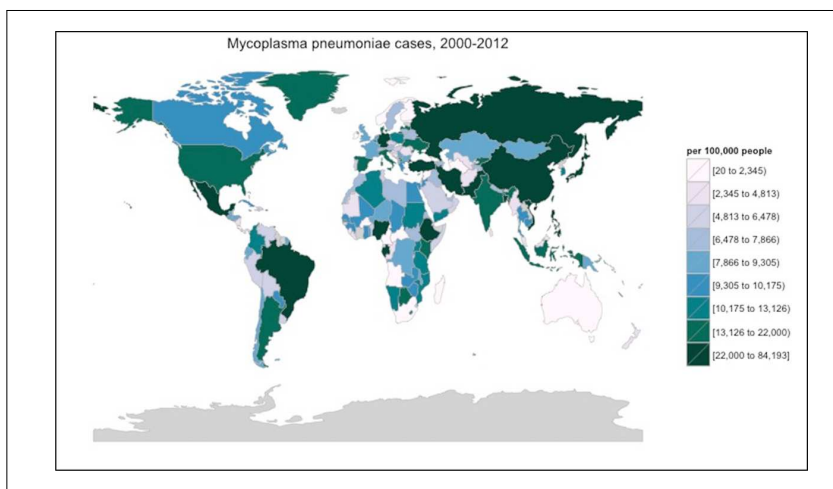

FIGURE 3 | Interpolated M. pneumoniae incidence from 2000 to 2012. These statistics were calculated using linear interpolation from reported incidence found within the literature. Gray countries were incalculable. This interpolation process did not take into account any genetic, cultural, environmental, social, or other differences across the various countries and regions. Thus, interpolations may have very limited relevance to the actual incidence of $M$. pneumoniae in any region. Image created using $R$ v.3.2.2 with the package choroplethr.

the developmentally disabled or elderly (Marrie, 1993; Klausner et al., 1998; Hastings et al., 2015). Although, these outbreaks can disrupt and consume significant resources in the workforce, longterm morbidity is uncommon (Waites and Talkington, 2004). Controlling an outbreak often includes simple strategies such as, cohorting infected patients and the correct use of antibiotics as treatment.

\section{CLINICAL MANIFESTATIONS}

In the acute phase of infection, a dry cough develops which may progress to a wet cough in 3-4 days. Coughing represents progressing tracheobronchitis, the most common form of infection. Chest auscultation may be unhelpful for diagnosis in most situations, but scattered rhonchi and expiratory wheezes may sometimes present (Norisue et al., 2008). If pneumonia develops, atypical pneumonia is the predominant syndrome observed in adult patients. The syndrome is portrayed by the gradual onset of pharyngitis, sinus congestion, infrequent otitis media, and eventually prolonged lower respiratory involvement up to and including pneumonia with low-grade fever and bibasilar pulmonary infiltrates. The incubation period prior to symptom emergence may be short or as long as 3 weeks. In severe pneumonia cases, dry rales and frank consolidation may be observed, but this is fairly uncommon, and may be due to co-infection with Streptococcus pneumoniae or Chlamydophila pneumoniae (Nambu et al., 2006; Norisue et al., 2008).

There may be mild leukocytosis, but the total white blood cell count does not often exceed 15,000/ $\mu$ L. Expectorated sputum is not viscous. If sputum is sufficient, gram staining shows nothing discernable due to the small size of $M$. pneumoniae and its lack of cell wall. Severe cough and chest images depicting bronchopneumonia are common, as inflammation occurs in response to ciliated cell damage. Respiratory symptoms in severe pneumonia cases may necessitate admission to the hospital due 
to decreased blood oxygen and increasingly labored breathing. The most common radiological and high resolution computed tomography (CT) images of $M$. pneumoniae pneumonia include air-space opacification, bronchovascular thickening, atelectasis, nodular infiltration, and linear opacities outward from the hilum, but are indistinguishable from other bacterial or viral pneumonia patterns (Reittner et al., 2000; Miyashita et al., 2009). Putman et al. (1975) proposed three possible reasons for alternate chest images: the existence of an underlying or co-existing pulmonary disease, previous exposure to M. pneumoniae, or the varied immune response and host susceptibility. To date, many researchers favor prior exposure (Saraya et al., 2011; Medina et al., 2012) and host immune differences (Tanaka et al., 1996; Saraya et al., 2014). Still, others report alternate host differences such as age (Lee et al., 2006), health conditions (Lambert, 1968), or environmental factors (Putman et al., 1975; Yang et al., 2004). Severity of disease has also been shown to be strain- and toxin concentration-dependent (Techasaensiri et al., 2010).

As mentioned previously, the cell-mediated immunity of patients may have a strong impact on the course of disease development following M. pneumoniae infection (Putman et al., 1975; Tanaka et al., 1996; Yang et al., 2002; Saraya et al., 2011, 2014). Some studies report detection of M. pneumoniae in seemingly healthy individuals. One such study reports peak incidence of $13.5 \%$ of 758 healthy volunteers (Gnarpe et al., 1992), while another study detected positive throat cultures 4 months after illness (Foy et al., 1966). It is possible these asymptomatic or mild infections still allow for shedding of the pathogen. These patients may act as a reservoir from which further spreading can occur. Similar to other respiratory infections, the duration of signs and symptoms will be shorter if antibiotics are initiated early in the course of infection.

\section{Other Respiratory Manifestations}

It has been suggested $M$. pneumoniae infection contributes to the development of chronic respiratory diseases, including persistent cough and asthma. While medical care for a persistent cough is frequently sought out, this symptom is commonly associated with M. pneumoniae in children (Hallander et al., 1999; Wang et al., 2011) and older adults (Miyashita et al., 2008; Takahashi et al., 2009). The organism may be found frequently in school-aged children with persistent cough particularly during active epidemics of M. pneumoniae (Wang et al., 2011) or concurrently with Bordetella pertussis (Hallander et al., 1999). Similar outbreaks of persistent cough are likely to occur in other ideal settings, such as dormitories, among military recruits, and in hospitals or nursing homes. In Japan, M. pneumoniae was confirmed by serology in $5.5 \%$ of adult patients with persistent cough (Ishida et al., 2010). Despite this evidence, Wadowsky et al. (2002), concludes M. pneumoniae is infrequently the active agent of cough illnesses longer than 5 days in adolescents and adults. However, cough may persist after acute infection in adults due to the continued presence of mycoplasma cell products or the CARDS toxin (Kannan et al., 2011).

Mycoplasma pneumoniae has for a long time been implicated in the exacerbation of asthma (Biscardi et al., 2004; Nisar et al., 2007; Hong, 2012; Wood et al., 2013). Moreover, some studies have isolated the bacteria in higher prevalence among asthmatics (Kraft et al., 1998; Smith-Norowitz et al., 2013). Sutherland et al. (2004), evaluated a questionnaire given to patients with a history of CAP after an episode of pneumonia. There, patients with a history of atypical pneumonia were more likely to be asthmatics. Other studies go on to document $M$. pneumoniae infection preceding an initial asthmatic event (Mok et al., 1979; Yano et al., 1994; Biscardi et al., 2004). It is possible mycoplasma infection leads to the destruction of respiratory cells and facilitates mucosal penetration by other antigens. Thereby, allowing the patient to become atopic to M. pneumoniae and other allergens (Nisar et al., 2007). However, at this time, none of these studies have distinguished increased susceptibility or exposure to $M$. pneumoniae from genetic predisposition for asthma (Mok et al., 1979).

Although, the M. pneumoniae connection with asthma is wellestablished, the mechanism behind development of the disease is still relatively unknown. One clue to pathogenesis in this regard may be immunoglobin (Ig) E responses. Some studies have reported control patients, may be capable of mounting a higher antibody response than those with asthma (Kraft et al., 2002; Atkinson et al., 2009; Wood et al., 2013). The role of $\mathrm{T}$ lymphocytes in the pathogenesis of asthma has been well-documented. The release of type 2 cytokines, including interleukin (IL)-4 and 5, is also increased in the serum of patients with M. pneumoniae (Esposito et al., 2002; Jeong et al., 2012). These cytokines in turn promote IgE production, which also plays a part in asthma. Also, antigenic mycoplasmas may initiate an antibody response resulting in $\operatorname{IgE}$ attaching to mast cells interacting with $M$. pneumoniae, which ultimately stimulates histamine release (Gil et al., 1993). However, additional studies are needed to fully understand the role of $M$. pneumoniae plays in the initial onset and exacerbation of asthma.

\section{Extrapulmonary Manifestations}

Extrapulmonary manifestations, although less common, have also been described. Patients with compromised immunity, including humoral immunodeficiences may be at higher risk for developing these complications. Extrapulmonary complications may occur in no more than $10 \%$ of patients with $M$. pneumoniae. Central nervous system (CNS) complications comprise the bulk of commonly seen extrapulmonary manifestations (Guleria et al., 2005). Such complications include, encephalitis, meningitis, optic neuritis, and Guillain-Barré syndrome among others. The mechanism of action behind these ominous manifestations remains unknown. In most patients, respiratory illness precedes, 2-14 days before, CNS findings (Tsiodras et al., 2005). CNS complications may result from direct invasion of $M$. pneumoniae in the brain (Tsiodras et al., 2005) or through extreme immune-mediated damages (Lee et al., 2013). Immune-mediated responses could be the result of cross-reacting antibodies and antigens shared by $M$. pneumoniae and the brain, depression of T-lymphocyte function, immune complex deposition, or intravascular clotting (Guleria et al., 2005; Tsiodras et al., 2005; Johnson, 2006).

Dermatological conditions such as erythematous maculopapular, vesicular rashes and Stevens-Johnson syndrome, 
are also somewhat common as extrapulmonary manifestations (Walicka et al., 2008; Kashyap and Sarkar, 2010; Kunimi et al., 2011; Shimizu et al., 2012). Whereas, hematological, gastrointestinal, musculoskeletal, renal and other inflammatory manifestations have occurred in rare cases (Cameron et al., 1992; Perez et al., 1997; Parisi and Filice, 2001; Perez and Artola, 2001; Waites and Talkington, 2004; Johnson et al., 2007; Atkinson et al., 2008; Maia et al., 2009; Kashyap and Sarkar, 2010; Bayram et al., 2011). Further, information regarding the details of extrapulmonary diseases as a result of $M$. pneumoniae can be found in numerous case reports. However, because M. pneumoniae is quite common, there is the possibility some of these instances are only coincidental.

\section{DIAGNOSIS}

As a common cause of illness for both children and adults, M. pneumoniae should regularly be considered as a possible etiology in any upper respiratory infection, especially in immunocompromised patients or patients who have not responded to $\beta$-lactam antibiotics. Recently, there are many new techniques adapted to detecting the presence of $M$. pneumoniae suitable for both research and diagnostic purposes. These techniques were described in length by Daxboeck et al. (2003). Here, we will include a brief review and updated techniques.

The Japanese Respiratory Society (JRS) developed a scoring system to differentiate between typical and atypical pneumonia (Ishida et al., 2007) using clinical findings. The differential items include: (1) patient under 60 years of age; (2) no or minor underlying diseases; (3) stubborn cough; (4) poor chest auscultatory findings; (5) no sputum or etiologic agent identified by gram staining; and (6) a peripheral white blood cell below $10,000 / \mu \mathrm{L}$. In cases where a patient presents with four or more of the six items, JRS guidelines recommend the use of macrolides or tetracyclines because of a suspected atypical pneumonia.

Many countries consider the most reliable diagnosis for acute pneumonia infection would come from a combination of two or more separate laboratory methods, such as serology and PCR (Petitjean et al., 2002; Daxboeck et al., 2003; Martinez et al., 2008; Nilsson et al., 2008; Chaudhry et al., 2013), or a clinical prediction rule, such as the JRS scoring system, with a rapid laboratory test (Ishida et al., 2007; Miyashita et al., 2011, 2015). The use of the laboratory tests listed below along with clinical prediction rules can more easily distinguish among acute, persistent infection and asymptomatic patients.

Historically, the use of cold agglutinins and detection of M. pneumoniae by culture methods were widespread diagnostic techniques. Cold agglutinin testing was once considered a valuable tool, but it is not a highly specific indicator of M. pneumoniae, as autoantibodies in the blood can be elevated from other diseases or syndromes (Jacobs, 1993; Beersma et al., 2005). A decade ago, the complement fixation (CF) method that detects the human body's early responses to $M$. pneumoniae was common around the world. A single 1:64 CF titer was considered an indication of recent $M$. pneumoniae infection. However, the
CF test has a well-documented lack of sensitivity and specificity (Ponka et al., 1981; Waites and Talkington, 2004).

\section{Rapid Diagnostics}

Currently, a more advanced test using a similar method to $\mathrm{CF}$ is the microparticle agglutination assay (MAG), wherein specific antibodies to $M$. pneumoniae create hemagglutination and erythrocytes are replaced by latex particles to avoid nonspecific reactions (Barker et al., 1990). Additionally, in August 2013, two rapid antigen kits for the detection of $M$. pneumoniae in nasopharyngeal samples became available in Japan (Miyashita et al., 2015; Yamazaki et al., 2015). These rapid antigen kits detect two different targets L7/L12 ribosomal protein or P1 adhesion protein. Two studies have compared the ribosomal protein rapid antigen kit to real-time PCR and the resulting theoretical diagnostic sensitivities were approximately $60 \%$ (Miyashita et al., 2015) and 74\% (Yamazaki et al., 2015) in these samples. Hatano et al. (2013), reported the use of this rapid P1 adhesion protein detecting kit in 462 patients with a resulting sensitivity and specificity of 90 and $89.5 \%$, respectively. However, further prospective studies are needed to evaluate the sensitivity of these rapid tests more thoroughly.

Rapid diagnostic tests are most useful in the early stages of CAP to assist decisions related to patient therapy. Despite the development of these two tests, however, the majority of M. pneumoniae cases continue to be diagnosed using serological methods or through the detection of nucleic acids. A variety of tests have been developed in this regard, each with their own advantages and disadvantages. However, numerous confounding variables inherent to the pathogenesis of $M$. pneumoniae contribute to obscuring the diagnostic accuracy of laboratory methods.

\section{Serology}

Serology remains as relevant now as it was in the past for the diagnosis of $M$. pneumoniae. The ease of sample collection coupled with further regard to conclusive evidence of M. pneumoniae as the causative agent, maintain serology's presence within diagnostics. There are currently several commercially available serological tests utilizing a variety of methods to detect the presence of $M$. pneumoniae.

Enzyme immunoassays (EIAs) use whole-cell lysates, containing glycolipid antigens, or protein extracts without glycolipid antigens. IgG seroconversion in $M$. pneumoniae infected patients is estimated to occur from 3 to 8 weeks following infection. EIAs are more sensitive than both the CF and MAG tests (Moule et al., 1987; Aubert et al., 1992; Nir-Paz et al., 2006) for detecting acute infection. Most EIAs implement a 96 well-microtiter plate. However, rapid membrane based procedures are available for the detection of a single specimen (Alexander et al., 1996; Matas et al., 1998).

For diagnosis during acute infection, a separate detection of $\operatorname{IgM}$ or $\operatorname{IgA}$ is useful. $\operatorname{IgM}$ antibodies appear in the first week of illness and reach their highest titers during the third week (Jacobs, 1993). IgA antibodies are also produced in early stages of the disease (Watkins-Riedel et al., 2001). Assays for 
$\operatorname{IgM}$ and IgA detection are primarily based on the enzymelinked immunosorbent assay (ELISA) principle. Rapid assays, like those previously mentioned are also available and generally use direct immunoflourescence, counter immunoelectrophoresis, immunoblotting or antigen capture EIs (Kashyap and Sarkar, 2010). Talkington et al. (2004) and Beersma et al. (2005), more thoroughly evaluated commercially available EIAs.

Despite its many strengths and versatility, serology lacks sensitivity. Many ELISA tests have the possibility of false positive results by cross-reactions with other mycoplasma species (Morrison-Plummer et al., 1987). Additionally, antibodies to M. pneumoniae may not appear until 2 weeks following initial infection and onset of symptoms (Vikerfors et al., 1988). Other studies report substantially longer times until positive serology results (Nir-Paz et al., 2006; Nilsson et al., 2008; Zhang et al., 2011). Further still, physicians must also consider the status of a patient's immune system. Particularly, in adults the response to IgM may be non-specific or absent (Uldum et al., 1992); while other underlying conditions may indicate an immunocompromised patient. However, serology as a diagnostic approach remains a convenient alternative for the detection of M. pneumoniae in respiratory secretions.

\section{Nucleic Acid Amplification}

Polymerase chain reaction amplification from respiratory secretions, such as nasopharyngeal, oropharyngeal, or sputum samples can provide more sensitive detection. Many studies have shown amplification methods can detect $M$. pneumoniae even in seemingly healthy individuals (Leng et al., 1994; Tjhie et al., 1997). PCR tests have been designed around the $16 \mathrm{~S}$ rDNA, P1 adhesion protein, and the ATPase operon genes of M. pneumoniae. Sensitivity can be further increased by nested PCR, which involves reamplification of a PCR product with a different set of primers for the same target.

Quantitative real-time PCR (qRT-PCR) may also provide an attractive alternative to serology and conventional PCR (Pitcher et al., 2006). It is as sensitive as conventional PCR with the additional possibility of quantitative capabilities, which may indicate acute infections. The qRT-PCR method has also been successful for rapidly and reliably distinguishing between the two dominant M. pneumoniae types (Schwartz et al., 2009). Furthermore, a qRT-PCR assay, designed to target the CARDS toxin gene, proved to be the most sensitive assay to identify positive specimens in an outbreak investigation and again in other specimens (respiratory and cerebrospinal fluid) in sporadic cases (Winchell et al., 2008). Currently, a commercially available kit, implementing detection of the CARDS toxin gene does not exist. A publication authored by Chaudhry et al. (2013) indicates in-house qRT-PCR designed methods have a small but significant increase in sensitivity over traditional PCR methods, but primer design and standardization could be problematic for less experienced laboratories.

The use of conventional PCR and qRT-PCR has standardized the detection of M. pneumoniae along with other pneumonia and atypical pneumonia inducing bacterial pathogens (Mustafa et al., 2011). A recent study comparing four commercially available multiplex PCR assays found performance across different manufacturers remains relatively high and stable, with $93-100 \%$ agreement for all comparisons (Anderson et al., 2013). Khanna et al. (2005) developed a multiplex PCR assay for detection of five pneumonia-causing bacteria; it is now available commercially. The use of multiplex PCR or multiplex qRT-PCR technology enables the detection of multiple pathogens simultaneously with excellent sensitivity and specificity. Multiplex technology is particularly useful for the diagnosis of CAP patients, in etiological studies, or when broad-spectrum antibiotics fail to improve patient conditions.

Developed in Japan, a new amplification technique called loop-mediated isothermal amplification (LAMP) has also been applied to rapid diagnosis of M. pneumoniae (Saito et al., 2005; Yoshino et al., 2008; Kakuya et al., 2014). This molecular amplification method occurs in a single tube at constant temperature, eliminating the necessity of a thermocycler. Endpoint analysis can be performed rapidly by visual confirmation of turbidity and precipitates or can be integrated into more advanced photometrics for more accurate quantification. The sensitivity of the LAMP assay was $88.5 \%$ compared to a validated qRT-PCR test on samples collected in the United States, and no cross reactivity was observed against 17 other mycoplasma species, human DNA, nor other common respiratory pathogens (Petrone et al., 2015). Unfortunately, due to the limits inherent within primer design, multiplexing of this assay is not possible. In the near future LAMP assays could enable rapid, low cost detection of $M$. pneumoniae cases and earlier recognition of outbreaks by medical providers (Petrone et al., 2015), particularly in resource limited settings.

\section{Culture Techniques}

Although still seen as the "gold standard," bacterial culture for M. pneumoniae from oropharyngeal samples can be time consuming due to the nutritive requirements. Specificity is $100 \%$, when protocols are successful. Isolation of the pathogen has advanced the knowledge surrounding extrapulmonary manifestations, because successful isolation provides evidence of direct invasion by living bacteria (Daxboeck et al., 2003). Similar conclusions cannot be made from all positive PCR results, because target DNA may still be detected in patients beyond the death of the bacteria. However, the sensitivity of culture for diagnosis can be low and dependent both on the skill of the laboratory as well as the quality of the specimen. Thus, M. pneumoniae is cultured with cell-free media formulations, primarily for research purposes.

\section{CHEMOTHERAPY AND VACCINES}

These organisms lack a peptidoglycan cell wall, therefore therapy, which interferes with DNA synthesis, i.e., quinolones, or protein synthesis such as, macrolides and tetracyclines, are used more frequently than beta-lactams and glycopeptides and generally have a greater influence on disease (Niederman, 2001; Watkins and Lemonovich, 2011). For young children, macrolides should be considered first, due to potential severe side effects of tetracyclines and quinolones (Suzuki et al., 2006). 
Macrolides are well-known for their antibiotic capabilities. However, considerable data has also been gathered confirming macrolides also possess anti-inflammatory properties, which can also contribute to patient improvement (Gotfried, 2004; Tamaoki, 2004). Macrolides seem to modify or regulate the immune system by inhibiting inflammatory cell chemotaxis, cytokine synthesis, adhesion molecule expression, reactive oxygen species production and intracellular signaling pathways (Kanoh and Rubin, 2010). A study conducted by Kraft et al. (2002) focused on the effect of clarithromycin on lung function of M. pneumoniae infected and uninfected asthmatic patients. They determined clarithromycin treatment caused improvement in forced expiratory volume and reduced airway expression of IL5 , but only in M. pneumoniae positive patients. These findings suggest, in cases of $M$. pneumoniae, macrolides may act primarily as antibiotics as well as an anti-inflammatory agent. The optimal dosage and duration of therapy is not clear; however, 10-14 days is generally recommended. The use of steroids in combination with macrolides has also been recommended in severe cases of M. pneumoniae pneumonia.

Macrolide-resistant M. pneumoniae was first reported in Japan in Okazaki et al. (2001) and has since been continuously reported in increasing percentages among the population (Matsuoka et al., 2004; Miyashita et al., 2012, 2013; Kawai et al., 2013; Hanada et al., 2014). However, the prevalence of macrolide-resistant M. pneumoniae varies among countries. Cao et al. (2010), China documented a $69 \%$ prevalence of resistance as well as treatment failure, but no cases of macrolide-resistant $M$. pneumoniae were found from 1997 to 2008 in the Netherlands (Spuesens et al., 2012). It is well-established, point mutations, leading to A-to$\mathrm{G}$ transitions in the peptidyl transferase loop domain $\mathrm{V}$ of the 23S rRNA gene at positions 2063 and 2064, reduce the affinity of macrolide for the ribosome (Suzuki et al., 2006; Dumke et al., 2010a). Identification of these resistant strains currently relies on restriction fragment length polymorphism or gene sequence analysis. The creation of a laboratory technique, such as qRTPCR to rapidly detect macrolide resistant strains may be useful for surveillance and outbreak situation.

Of the major bacterial respiratory pathogens including Streptococcus pneumoniae and Haemophilus influenzae, M. pneumoniae is the only one without an available vaccine (Nir-Paz et al., 2012). During the 1960 and 1970s a number of studies were carried out testing immunogenicity and the protective efficacy of several different vaccines. A recent metaanalysis by Linchevski et al. (2009), has shown the overall pneumonia prevention efficacy of those studies was $41 \%$ (54\% for M. pneumoniae specific pneumonia), when diagnosis was based on culture or serology. No serious adverse effects were reported and only mild local reactions were suffered.

Schurwanz et al. (2009), P1 and P30 adhesions showed strong reactivity with human and animal sera, proving as promising candidates for further vaccine formulation and optimization. However, in 2011 study reported vaccination with only an avirulent P30 mutant resulted in disease exacerbation in mice (Szczepanek et al., 2012). Most recently though the subcutaneous administration of a P1-P30 chimeric recombinant protein, followed by two intranasal booster administrations induced high, consistent, and long lasting IgA levels in guinea pigs (Hausner et al., 2013). The CARDS toxin could also serve as an effective vaccine candidate (Kannan et al., 2011).

Mycoplasma pneumoniae is increasingly the cause of upper and lower respiratory tract infections for adults and children. It is associated with prolonged carriage and lacks natural protective immunity following primary infections. Continued development of a vaccine for high-risk individuals such as school children, military recruits, and elderly people in nursing homes or long term hospital care, may help to reduce morbidity from pneumonia and secondary complications. A vaccine may also slow the development of other macrolide resistant strains and reduce the impact of macrolide-resistant strains in communities and epidemics.

\section{CONCLUSION}

Mycoplasma pneumoniae is a commonly found pathogen within adults around the world. It is a common cause of pneumonia but can also initiate other extrapulmonary manifestations. The simplicity of the genome and the small size of mycoplasmas have led many to conclude these organisms are uncomplicated. In reality, much regarding the microbiology and pathogenesis of this organism remains unknown. A variety of respiratory diseases portray similar clinical symptoms. Recent and continued advances in multiplex PCR and qRT-PCR may prove useful in distinguishing the pathogen causing disease. In many situations, the mild symptoms of $M$. pneumoniae pneumonia may be ignored by the patient and remain undiagnosed.

Much energy has been devoted to the CARDS toxin. Information regarding its structure and involvement in pathogenesis may prove useful to the continued development of more effective options for both diagnostics and therapies. Currently, there is limited availability of rapid and accurate testing methods for $M$. pneumoniae. Further development of rapid tests specifically to distinguish macrolide-resistant strains may also be useful within Asia. Physicians and patients around the world must continue to monitor macrolide-resistance strains, preventing dissemination and increased incidence. However, the development of an effective vaccine could prove useful at reducing the burden among the elderly and within the workforce around the world.

\section{AUTHOR CONTRIBUTIONS}

GP and TK made substantial contributions to the conception and design of the work. GP primarily drafted the work and TK and JF revised it critically for important intellectual content. All had final approval of the version to be published and agree to be accountable for all aspects of the work in ensuring that questions related to the accuracy or integrity of any part of the work are appropriately investigated and resolved.

\section{ACKNOWLEDGMENTS}

We thank Matthew T. Roseler and Stephanie Untz for their expertise in creating the figures included in this document. 


\section{REFERENCES}

Accomando, S., Trizzino, A., Montaperto, D., Barcellona, R., and Amato, G. M. (2004). Mycoplasma pneumonias distribution, epidemiology and prevalence in a triennial survey. Pediatr. Med. Chir. 26, 434-438.

Alexander, E. R., Foy, H. M., Kenny, G. E., Kronmal, R. A., McMahan, R., Clarke, E. R., et al. (1966). Pneumonia due to Mycoplasma pneumoniae. Its incidence in the membership of a co-operative medical group. N. Engl. J. Med. 275, 131-136. doi: 10.1056/NEJM196607212750303

Alexander, T. S., Gray, L. D., Kraft, J. A., Leland, D. S., Nikaido, M. T., and Willis, D. H. (1996). Performance of Meridian ImmunoCard Mycoplasma test in a multicenter clinical trial. J. Clin. Microbiol. 34, 1180-1183.

Anderson, T. P., Werno, A. M., Barratt, K., Mahagamasekera, P., Murdoch, D. R., and Jennings, L. C. (2013). Comparison of four multiplex PCR assays for the detection of viral pathogens in respiratory specimens. J. Virol. Methods 191, 118-121. doi: 10.1016/j.jviromet.2013.04.005

Arnold, F. W., Summersgill, J. T., Lajoie, A. S., Peyrani, P., Marrie, T. J., Rossi, P. et al. (2007). A worldwide perspective of atypical pathogens in communityacquired pneumonia. Am. J. Respir. Crit. Care Med. 175, 1086-1093. doi: 10.1164/rccm.200603-350OC

Atkinson, T. P., Balish, M. F., and Waites, K. B. (2008). Epidemiology, clinical manifestations, pathogenesis and laboratory detection of Mycoplasma pneumoniae infections. FEMS Microbiol. Rev. 32, 956-973. doi: 10.1111/j.15746976.2008.00129.x

Atkinson, T. P., Duffy, L. B., Pendley, D., Dai, Y., and Cassell, G. H. (2009). Deficient immune response to Mycoplasma pneumoniae in childhood asthma. Allergy Asthma Proc. 30, 158-165. doi: 10.2500/aap.2009.30.3207

Aubert, G., Pozzetto, B., Hafid, J., and Gaudin, O. G. (1992). Immunoblotting patterns with Mycoplasma pneumoniae of serum specimens from infected and non-infected subjects. J. Med. Microbiol. 36, 341-346. doi: 10.1099/0022261536-5-341

Bajraktarevic, A., Skopljak, A., Putica, S., Kumasin, L., Kreso, N. D., Djukic, B., et al. (2012). Prevalence bacterial and viral pneumonia in children on pediatrics pulmonology units during last three years period in Sarajevo. Int. J. Infect. Dis. 16(Suppl. 1):e196. doi: 10.1016/j.ijid.2012.05.770

Balish, M. F. (2006). Subcellular structures of mycoplasmas. Front. Biosci. 11:2027. doi: $10.2741 / 1943$

Balish, M. F., and Krause, D. C. (2006). Mycoplasmas: a distinct cytoskeleton for wall-less bacteria. J. Mol. Microbiol. Biotechnol. 11, 244-255. doi: $10.1159 / 000094058$

Barker, C. E., Sillis, M., and Wreghitt, T. G. (1990). Evaluation of Serodia Myco II particle agglutination test for detecting Mycoplasma pneumoniae antibody: comparison with mu-capture ELISA and indirect immunofluorescence. J. Clin. Pathol. 43, 163-165. doi: 10.1136/jcp.43.2.163

Bayram, A., Erdogan, M. B., Eksi, F., and Yamak, B. (2011). Demonstration of Chlamydophila pneumoniae, Mycoplasma pneumoniae, Cytomegalovirus, and Epstein-Barr virus in atherosclerotic coronary arteries, nonrheumatic calcific aortic and rheumatic stenotic mitral valves by polymerase chain reaction. Anadolu. Kardiyol. Derg. 11, 237-243. doi: 10.5152/akd. 2011.057

Becker, A., Kannan, T. R., Taylor, A. B., Pakhomova, O. N., Zhang, Y., Somarajan, S. R., et al. (2015). Structure of CARDS toxin, a unique ADP-ribosylating and vacuolating cytotoxin from Mycoplasma pneumoniae. Proc. Natl. Acad. Sci. U.S.A. 112, 5165-5170. doi: 10.1073/pnas.14203 08112

Beersma, M. F., Dirven, K., van Dam, A. P., Templeton, K. E., Claas, E. C., and Goossens, H. (2005). Evaluation of 12 commercial tests and the complement fixation test for Mycoplasma pneumoniae-specific immunoglobulin G (IgG) and IgM antibodies, with PCR used as the "gold standard". J. Clin. Microbiol. 43, 2277-2285. doi: 10.1128/JCM.43.5.2277-2285.2005

Bii, C. C., Yamaguchi, H., Kai, M., Nagai, K., Sugiura, Y., Taguchi, H., et al. (2002). Mycoplasma pneumoniae in children with pneumonia at Mbagathi District Hospital, Nairobi. East. Afr. Med. J. 79, 317-322. doi: 10.4314/eamj.v79i6.8852

Biscardi, S., Lorrot, M., Marc, E., Moulin, F., Boutonnat-Faucher, B., Heilbronner, C., et al. (2004). Mycoplasma pneumoniae and asthma in children. Clin. Infect. Dis. 38, 1341-1346. doi: 10.1086/392498

Bischoff, S. C., Krieger, M., Brunner, T., Rot, A., von Tscharner, V., Baggiolini, M., et al. (1993). RANTES and related chemokines activate human basophil granulocytes through different G protein-coupled receptors. Eur. J. Immunol. 23, 761-767. doi: 10.1002/eji.1830230329

Blystad, H., Anestad, G., Vestrheim, D. F., Madsen, S., and Ronning, K. (2012). Increased incidence of Mycoplasma pneumoniae infection in Norway 2011. Euro Surveill. 17:20074.

Boettcher, M. W., Baetz, O., Kramer, J., Hempel, M., Dettlaff, S., and Wellinghausen, N. (2010). Seroprevalence and season variation of Chlamydia pneumoniae and Mycoplasma pneumoniae infection in Germany [poster]. Clin. Microbiol. Infect. 16:S6667.

Bose, S., Segovia, J. A., Somarajan, S. R., Chang, T. H., Kannan, T. R., and Baseman, J. B. (2014). ADP-ribosylation of NLRP3 by Mycoplasma pneumoniae CARDS toxin regulates inflammasome activity. MBio 5:e02186. doi: $10.1128 / \mathrm{mBio} .02186-14$

Bredt, W. (1968). Motility and multiplication of Mycoplasma pneumoniae. A phase contrast study. Pathol. Microbiol. (Basel) 32, 321-326.

Broaders, S. A., Hooper, W. C., Phillips, D. J., and Talkington, D. F. (2006). Mycoplasma pneumoniae subtype-independent induction of proinflammatory cytokines in THP-1 cells. Microb. Pathog. 40, 286-292. doi: 10.1016/j.micpath.2006.03.002

Cameron, D., Welsby, P., and Turner, M. (1992). Thrombotic thrombocytopenic purpura due to Mycoplasma pneumoniae. Postgrad. Med. J. 68, 393-394. doi: 10.1136/pgmj.68.799.393

Campos, E., Bolanos, H., Serra, J., Ramirez, J. A., Barboza, O., and Jacobs, E. (1993). Mycoplasma pneumoniae infections in schoolchildren of a tropical community. Rev. Biol. Trop. 41, 371-377.

Cao, B., Zhao, C. J., Yin, Y. D., Zhao, F., Song, S. F., Bai, L., et al. (2010). High prevalence of macrolide resistance in Mycoplasma pneumoniae isolates from adult and adolescent patients with respiratory tract infection in China. Clin. Infect. Dis. 51, 189-194. doi: 10.1086/653535

Carrim, M. W., Du PLessis, N., De Gouveia, M., Walaza, L., Variava, S., Moosa, E., et al. (2014). Molecular detection of Mycoplasma pneumoniae among patients with severe respiratory and influeza-like illness in South Africa, 2012-2013. Int. J. Infect. Dis. 21(Suppl.):345. doi: 10.1016/j.ijid.2014.03.1132

Centers for Disease Control and Prevention [CDC] (2012). Mycoplasma pneumoniae respiratory illness - two rural counties, West Virginia, 2011. Morb. Mortal. Wkly. Rep. 61, 834-838.

Centers for Disease Control and Prevention [CDC] (2013). Mycoplasma pneumoniae outbreak at a university - Georgia, 2012. Morb. Mortal. Wkly Rep. 62, 603-606.

Chalker, V., Stocki, T., Mentasti, M., Fleming, D., and Harrison, T. (2011). Increased incidence of Mycoplasma pneumoniae infection in England and Wales in 2010: multiocus variable number tandem repeat analysis typing and macrolide susceptibility. Euro Surveill. 16:19865.

Chanock, R. M., Cook, M. K., Fox, H. H., Parrott, R. H., and Huebner, R. J. (1960). Serologic evidence of infection with Eaton agent in lower respiratory illness in childhood. N. Engl. J. Med. 262, 648-654. doi: 10.1056/NEJM196003312621303

Chanock, R. M., Hayflick, L., and Barile, M. F. (1962). Growth on artificial medium of an agent associated with atypical pneumonia and its identification as a PPL. Proc. Natl. Acad. Sci. U.S.A. 48, 41-49. doi: 10.1073/pnas.48.1.41

Chanock, R. M., Rifkind, D., Kravetz, H. M., Kinght, V., and Johnson, K. M. (1961). Respiratory disease in volunteers infected with Eaton agent: a preliminary report. Proc. Natl. Acad. Sci. U.S.A. 47, 887-890. doi: 10.1073/pnas.47.6.887

Chaoprasong, C., Chanthadisai, N., Buasap, U., Tirawatnapong, S., and Wattanathum, A. (2002). Mycoplasma pneumoniae community-acquired pneumonia at three hospitals in Bangkok. J. Med. Assoc. Thai. 85, 643-647.

Chaudhry, R., Sharma, S., Javed, S., Passi, K., Dey, A. B., and Malhotra, P. (2013). Molecular detection of Mycoplasma pneumoniae by quantitative real-time PCR in patients with community acquired pneumonia. Indian J. Med. Res. 138, 244-251.

Chaudhry, R., Varshney, A. K., and Malhotra, P. (2007). Adhesion proteins of Mycoplasma pneumoniae. Front. Biosci. 12:699. doi: 10.2741/2093

Chen, F. Q., Yang, Y. Z., Yu, L. L., and Bi, C. B. (2015). Prevalence of Mycoplasma pneumoniae: a cause for community-acquired infection among pediatric populaztion. Niger. J. Clin. Pract. 18, 354-358. doi: 10.4103/1119-3077.153247

Chen, Z. R., Yan, Y. D., Wang, Y. Q., Zhu, H., Shao, X. J., Xu, J., et al. (2013). Epidemiology of community-acquired Mycoplasma pneumoniae respiratory tract infections among hospitalized Chinese children, including relationships with meteorological factors. Hippokratia 17, 20-26. 
Chu, H. W., Honour, J. M., Rawlinson, C. A., Harbeck, R. J., and Martin, R. J. (2003). Effects of respiratory Mycoplasma pneumoniae infection on allergeninduced bronchial hyperresponsiveness and lung inflammation in mice. Infect. Immun. 71, 1520-1526. doi: 10.1128/IAI.71.3.1520-1526.2003

Chu, H. W., Jeyaseelan, S., Rino, J. G., Voelker, D. R., Wexler, R. B., Campbell, K., et al. (2005). TLR2 signaling is critical for Mycoplasma pneumoniae-induced airway mucin expression. J. Immunol. 174, 5713-5719. doi: 10.4049/jimmunol.174.9.5713

Clyde, W. A. Jr. (1971). Mycoplasma pneumoniae pneumonia. Mil. Med. 136, 20-22.

Clyde, W. A. Jr. (1983). Mycoplasma pneumoniae respiratory disease symposium: summation and significance. Yale J. Biol. Med. 56, 523-527.

Collier, A. M. (1983). Attachment by mycoplasmas and its role in disease. Rev. Infect. Dis. 5(Suppl. 4), S685-S691. doi: 10.1093/clinids/5.Supplement_4.S685

Coultas, D. B., Samet, J. M., and Butler, C. (1986). Bronchiolitis obliterans due to Mycoplasma pneumoniae. West J. Med. 144, 471-474.

Crum, N. F., Russell, K. L., Kaplan, E. L., Wallace, M. R., Wu, J., Ashtari, P., et al. (2005). Pneumonia outbreak associated with group a Streptococcus species at a military training facility. Clin. Infect. Dis. 40, 511-518. doi: 10.1086/427502

Cunha, B. A., and Pherez, F. M. (2009). Mycoplasma pneumoniae communityacquired pneumonia (CAP) in the elderly: diagnostic significance of acute thrombocytosis. Heart Lung 38, 444-449. doi: 10.1016/j.hrtlng.2008.10.005

Daxboeck, F., Krause, R., and Wenisch, C. (2003). Laboratory diagnosis of Mycoplasma pneumoniae infection. Clin. Microbiol. Infect. 9, 263-273. doi: 10.1046/j.1469-0691.2003.00590.x

Dey, A. B., Chaudhry, R., Kumar, P., Nisar, N., and Nagarkar, K. M. (2000). Mycoplasma pneumoniae and community-acquired pneumonia. Natl. Med. J. India $13,66-70$.

Dorigo-Zetsma, J. W., Dankert, J., and Zaat, S. A. (2000). Genotyping of Mycoplasma pneumoniae clinical isolates reveals eight $\mathrm{P} 1$ subtypes within two genomic groups. J. Clin. Microbiol. 38, 965-970.

Dumke, R., von Baum, H., Luck, P. C., and Jacobs, E. (2010a). Occurrence of macrolide-resistant Mycoplasma pneumoniae strains in Germany. Clin. Microbiol. Infect. 16, 613-616. doi: 10.1111/j.1469-0691.2009.02968.x

Dumke, R., Von Baum, H., Luck, P. C., and Jacobs, E. (2010b). Subtypes and variants of Mycoplasma pneumoniae: local and temporal changes in Germany 2003-2006 and absence of a correlation between the genotype in the respiratory tract and the occurrence of genotype-specific antibodies in the sera of infected patients. Epidemiol. Infect. 138, 1829-1837. doi: 10.1017/S0950268810000622

Eaton, M. D., Meiklejohn, G., and van Herick, W. (1944). Studies on the etiology of primary atypical pneumonia: a filterable agent transmissible to cotton rats, hamsters, and chick embryos. J. Exp. Med. 79, 649-668. doi: 10.1084/jem.79.6.649

Edwards, E. A., Crawford, Y. E., Pierce, W. E., and Peckinpaugh, R. O. (1976). A longitudinal study of Mycoplasma pneumoniae: infections in Navy recruits by isolation and seroepidemiology. Am. J. Epidemiol. 104, 556-562.

Eick, A. A., Faix, D. J., Tobler, S. K., Nevin, R. L., Lindler, L. E., Hu, Z., et al. (2011). Serosurvey of bacterial and viral respiratory pathogens among deployed U.S. service members. Am. J. Prev. Med. 41, 573-580. doi: 10.1016/j.amepre.2011.08.006

Esposito, S., Droghetti, R., Bosis, S., Claut, L., Marchisio, P., and Principi, N. (2002). Cytokine secretion in children with acute Mycoplasma pneumoniae infection and wheeze. Pediatr. Pulmonol. 34, 122-127. doi: 10.1002/ppul.10139

Fan, J., Frey, R. S., and Malik, A. B. (2003). TLR4 signaling induces TLR2 expression in endothelial cells via neutrophil NADPH oxidase. J. Clin. Invest. 112, 12341243. doi: 10.1172/JCI18696

Feikin, D. R., Moroney, J. F., Talkington, D. F., Thacker, W. L., Code, J. E., Schwartz, L. A., et al. (1999). An outbreak of acute respiratory disease caused by Mycoplasma pneumoniae and adenovirus at a federal service training academy: new implications from an old scenario. Clin. Infect. Dis. 29, 1545-1550. doi: $10.1086 / 313500$

Feikin, D. R., Njenga, M. K., Bigogo, G., Aura, B., Aol, G., Audi, A., et al. (2012). Etiology and Incidence of viral and bacterial acute respiratory illness among older children and adults in rural western Kenya, 2007-2010. PLoS ONE 7:e43656. doi: 10.1371/journal.pone.0043656

Fischman, R. A., Marschall, K. E., Kislak, J. W., and Greenbaum, D. M. (1978). Adult respiratory distress syndrome caused by Mycoplasma pneumoniae. Chest 74, 471-473. doi: 10.1378/chest.74.4.471
Fonseca-Aten, M., Rios, A. M., Mejias, A., Chavez-Bueno, S., Katz, K., Gomez, A. M., et al. (2005). Mycoplasma pneumoniae induces host-dependent pulmonary inflammation and airway obstruction in mice. Am. J. Respir. Cell Mol. Biol. 32, 201-210. doi: 10.1165/rcmb.2004-0197OC

Foy, H. M., Grayston, J. T., Kenny, G. E., Alexander, E. R., and McMahan, R. (1966). Epidemiology of Mycoplasma pneumoniae infection in families. JAMA 197, 859-866. doi: 10.1001/jama.197.11.859

Foy, H. M., Kenny, G. E., Cooney, M. K., and Allan, I. D. (1979). Long-term epidemiology of infections with Mycoplasma pneumoniae. J. Infect. Dis. 139, 681-687. doi: 10.1093/infdis/139.6.681

Franchi, L., Munoz-Planillo, R., and Nunez, G. (2012). Sensing and reacting to microbes through the inflammasomes. Nat. Immunol. 13, 325-332. doi: 10.1038/ni.2231

Franchi, L., and Nunez, G. (2012). Immunology. Orchestrating inflammasomes. Science 337, 1299-1300. doi: 10.1126/science.1229010

Gil, J. C., Cedillo, R. L., Mayagoitia, B. G., and Paz, M. D. (1993). Isolation of Mycoplasma pneumoniae from asthmatic patients. Ann. Allergy 70, 23-25.

Gnarpe, J., Lundback, A., Sundelof, B., and Gnarpe, H. (1992). Prevalence of Mycoplasma pneumoniae in subjectively healthy individuals. Scand. J. Infect. Dis. 24, 161-164. doi: 10.3109/00365549209052607

Golubjatnikov, R., Allen, V. D., Olmos-Blancarte, M. P., and Inhorn, S. L. (1975). Serologic profile of children in a Mexican highland community: prevalence of complement-fixing antibodies to Mycoplasma pneumoniae, respiratory syncytial virus and parainfluenza viruses. Am. J. Epidemiol. 101, 458-464.

Gotfried, M. H. (2004). Macrolides for the treatment of chronic sinusitis, asthma, and COPD. Chest 125, 52S-60S. doi: 10.1378/chest.125.2_suppl.52S

Grassi, T., Mancini, F., Ciervo, A., Vescio, M. F., Ghazal, A., Ashour, H., et al. (2014). Chlamydophila pneumoniae, Mycoplasma pneumoniae, and influenza in children with respiratory infections in Alexandria, Egypt. J. Infect. Dev. Ctries 8, 379-383. doi: $10.3855 /$ jidc. 4458

Gray, G. C., Callahan, J. D., Hawksworth, A. W., Fisher, C. A., and Gaydos, J. C. (1999). Respiratory diseases among U.S. military personnel: countering emerging threats. Emerg. Infect. Dis. 5, 379-385. doi: 10.3201/eid0503.990308

Gray, G. C., Duffy, L. B., Paver, R. J., Putnam, S. D., Reynolds, R. J., and Cassell, G. H. (1997). Mycoplasma pneumoniae: a frequent cause of pneumonia among U.S. Marines in southern California. Mil Med. 162, 524-526.

Guleria, R., Nisar, N., Chawla, T. C., and Biswas, N. R. (2005). Mycoplasma pneumoniae and central nervous system complications: a review. J. Lab. Clin. Med. 146, 55-63. doi: 10.1016/j.lab.2005.04.006

Hallander, H. O., Gnarpe, J., Gnarpe, H., and Olin, P. (1999). Bordetella pertussis, Bordetella parapertussis, Mycoplasma pneumoniae, Chlamydia pneumoniae and persistent cough in children. Scand. J. Infect. Dis. 31, 281-286. doi: 10.1080/00365549950163581

Hanada, S., Morozumi, M., Takahashi, Y., Mochizuki, S., Sato, T., Suzuki, S., et al. (2014). Community-acquired pneumonia caused by macrolide-resistant Mycoplasma pneumoniae in adults. Intern. Med. 53, 1675-1678. doi: 10.2169/internalmedicine.53.1418

Hardy, R. D., Coalson, J. J., Peters, J., Chaparro, A., Techasaensiri, C., Cantwell, A. M., et al. (2009). Analysis of pulmonary inflammation and function in the mouse and baboon after exposure to Mycoplasma pneumoniae CARDS toxin. PLoS ONE 4:e7562. doi: 10.1371/journal.pone.0007562

Hasselbring, B. M., and Krause, D. C. (2007). Proteins P24 and P41 function in the regulation of terminal-organelle development and gliding motility in Mycoplasma pneumoniae. J. Bacteriol. 189, 7442-7449. doi: 10.1128/JB. 00867-07

Hastings, D. L., Harrington, K. J., Kutty, P. K., Rayman, R. J., Spindola, D., Diaz, M. H., et al. (2015). Mycoplasma pneumoniae outbreak in a long-term care facility-Nebraska, 2014. MMWR Morb. Mortal. Wkly Rep. 64, 296-299.

Hatano, S., Komazawa, K., Nishimura, S., Fujie, A., Ono, R., Kawaguchi, H., et al. (2013). Comparison of diagnostic tests for Mycoplasma pneumoniae, including utility of rapid antigen kit for Mycoplasma pneumoniae. Shounikarinshou 66, 2105-2115.

Hatchel, J. M., and Balish, M. F. (2008). Attachment organelle ultrastructure correlates with phylogeny, not gliding motility properties, in Mycoplasma pneumoniae relatives. Microbiology 154, 286-295. doi: 10.1099/mic.0.2007/012765-0

Hausner, M., Schamberger, A., Naumann, W., Jacobs, E., and Dumke, R. (2013). Development of protective anti-Mycoplasma pneumoniae antibodies 
after immunization of guinea pigs with the combination of a P1-P30 chimeric recombinant protein and chitosan. Microb. Pathog. 64, 23-32. doi: 10.1016/j.micpath.2013.07.004

Hayashi, S., Ichikawa, Y., Fujino, K., Motomura, K., Kaji, M., Yasuda, K., et al. (1986). [Analysis of lymphocyte subsets in peripheral blood and bronchoalveolar lavage fluid in patients with pneumonia due to Mycoplasma pneumoniae]. Nihon Kyobu Shikkan Gakkai Zasshi 24, 162-167.

Hegermann, J., Herrmann, R., and Mayer, F. (2002). Cytoskeletal elements in the bacterium Mycoplasma pneumoniae. Naturwissenschaften 89, 453-458. doi: 10.1007/s00114-002-0359-2

Henderson, G. P., and Jensen, G. J. (2006). Three-dimensional structure of Mycoplasma pneumoniae's attachment organelle and a model for its role in gliding motility. Mol. Microbiol. 60, 376-385. doi: 10.1111/j.13652958.2006.05113.x

Himmelreich, R., Hilbert, H., Plagens, H., Pirkl, E., Li, B. C., and Herrmann, R. (1996). Complete sequence analysis of the genome of the bacterium Mycoplasma pneumoniae. Nucleic Acids Res. 24, 4420-4449. doi: $10.1093 /$ nar/24.22.4420

Hoffmann, J., Rabezanahary, H., Randriamarotia, M., Ratsimbasoa, A., Najjar, J., Vernet, G., et al. (2012). Viral and atypical bacterial etiology of acute respiratory infections in children under 5 years old living in a rural tropical area of Madagascar. PLoS ONE 7:e43666. doi: 10.1371/journal.pone.0043666

Hong, K. B., Choi, E. H., Lee, H. J., Lee, S. Y., Cho, E. Y., Choi, J. H., et al. (2013). Macrolide resistance of Mycoplasma pneumoniae, South Korea, 2000-2011. Emerg. Infect. Dis 19, 1281-1284. doi: 10.3201/eid1908.121455

Hong, S. J. (2012). The Role of Mycoplasma pneumoniae Infection in Asthma. Allergy Asthma Immunol. Res. 4, 59-61. doi: 10.4168/aair.2012.4.2.59

Huang, H.-H., Zhang, Y.-Y., Wang, F., Saniel, M., Alejandria, M., Park, S.-C., et al. (2008). A prevalence analysis of Mycoplasma pneumoniae and Chlamydia pneumoniae in Asian adults with community-acquired pneumonia. Chin. J. Infect. Chemother. 8, 89-93.

Hyde, T. B., Gilbert, M., Schwartz, S. B., Zell, E. R., Watt, J. P., Thacker, W. L., et al. (2001). Azithromycin prophylaxis during a hospital outbreak of Mycoplasma pneumoniae pneumonia. J. Infect. Dis. 183, 907-912. doi: 10.1086/319258

Ishida, T., Miyashita, N., and Nakahama, C. (2007). Clinical differentiation of atypical pneumonia using Japanese guidelines. Respirology 12, 104-110. doi: 10.1111/j.1440-1843.2006.00927.x

Ishida, T., Yokoyama, T., Iwasaku, M., Saigusa, M., Fukuyama, H., Nakagawa, H., et al. (2010). [Clinical investigation of postinfectious cough among adult patients with prolonged cough]. Nihon Kokyuki Gakkai Zasshi 48, 179-185.

Jacobs, E. (1993). Serological diagnosis of Mycoplasma pneumoniae infections: a critical review of current procedures. Clin. Infect. Dis. 17(Suppl. 1), S79-S82. doi: 10.1093/clinids/17.Supplement_1.S79

Jain, S., Self, W. H., Wunderink, R. G., Fakhran, S., Balk, R., Bramley, A. M., et al. (2015). Community- acquired pneumonia requiring hospitalization among U.S. Adults. N. Engl. J. Med. 373, 415-427. doi: 10.1056/NEJMoa1500245

Jeong, Y. C., Yeo, M. S., Kim, J. H., Lee, H. B., and Oh, J. W. (2012). Mycoplasma pneumoniae infection affects the serum levels of vascular endothelial growth factor and interleukin-5 in atopic children. Allergy Asthma Immunol. Res. 4, 92-97. doi: 10.4168/aair.2012.4.2.92

Johnson, C., Kannan, T. R., and Baseman, J. B. (2011). Cellular vacuoles induced by Mycoplasma pneumoniae CARDS toxin originate from Rab9-associated compartments. PLoS ONE 6:e22877. doi: 10.1371/journal.pone.0022877

Johnson, S. (2006). Possibly autoantibody complications in Mycoplasma pneumoniae infection. Clin. Infect. Dis. 43:1246. doi: 10.1086/508471

Johnson, S. M., Bruckner, F., and Collins, D. (2007). Distribution of Mycoplasma pneumoniae and Mycoplasma salivarium in the synovial fluid of arthritis patients. J. Clin. Microbiol. 45, 953-957. doi: 10.1128/JCM.01973-06

Joosting, A. C., Harwin, R. M., Coppin, A., Battaglia, P., and van der Hoef, P. (1976). A serological investigation of Mycoplasma pneumoniae infection on the Witwatersrand. S. Afr. Med. J. 50, 2134-2135.

Jordan, J. L., Chang, H. Y., Balish, M. F., Holt, L. S., Bose, S. R., Hasselbring, B. M., et al. (2007). Protein P200 is dispensable for Mycoplasma pneumoniae hemadsorption but not gliding motility or colonization of differentiated bronchial epithelium. Infect. Immun. 75, 518-522. doi: 10.1128/IAI.01344-06

Kakuya, F., Kinebuchi, T., Fujiyasu, H., Tanaka, R., and Kano, H. (2014). Genetic point-of-care diagnosis of Mycoplasma pneumoniae infection using LAMP assay. Pediatr. Int. 56, 547-552. doi: 10.1111/ped.12327
Kannan, T. R., and Baseman, J. B. (2006). ADP-ribosylating and vacuolating cytotoxin of Mycoplasma pneumoniae represents unique virulence determinant among bacterial pathogens. Proc. Natl. Acad. Sci. U.S.A. 103, 6724-6729. doi: 10.1073/pnas.0510644103

Kannan, T. R., Coalson, J. J., Cagle, M., Musatovova, O., Hardy, R. D., and Baseman, J. B. (2011). Synthesis and distribution of CARDS toxin during Mycoplasma pneumoniae infection in a murine model. J. Infect. Dis. 204, 1596-1604. doi: 10.1093/infdis/jir557

Kannan, T. R., Musatovova, O., Balasubramanian, S., Cagle, M., Jordan, J. L., Krunkosky, T. M., et al. (2010). Mycoplasma pneumoniae community acquired respiratory distress syndrome toxin expression reveals growth phase and infection-dependent regulation. Mol. Microbiol. 76, 1127-1141. doi: 10.1111/j.1365-2958.2010.07092.x

Kannan, T. R., Provenzano, D., Wright, J. R., and Baseman, J. B. (2005). Identification and characterization of human surfactant protein A binding protein of Mycoplasma pneumoniae. Infect. Immun. 73, 2828-2834. doi: 10.1128/IAI.73.5.2828-2834.2005

Kanoh, S., and Rubin, B. K. (2010). Mechanisms of action and clinical application of macrolides as immunomodulatory medications. Clin. Microbiol. Rev. 23, 590-615. doi: 10.1128/CMR.00078-09

Kashiwagi, S., Hayashi, J., Nomura, H., Kajiyama, W., Ikematsu, H., Shingu, T., et al. (1985). An outbreak of Mycoplasma pneumoniae infections in a hospital in Japan. Kurume Med. J. 32, 293-296. doi: 10.2739/kurumemedj.32.293

Kashyap, S., and Sarkar, M. (2010). Mycoplasma pneumonia: clinical features and management. Lung India 27, 75-85. doi: 10.4103/0970-2113.63611

Kawai, Y., Miyashita, N., Kubo, M., Akaike, H., Kato, A., Nishizawa, Y., et al. (2013). Nationwide surveillance of macrolide-resistant Mycoplasma pneumoniae infection in pediatric patients. Antimicrob. Agents Chemother. 57, 4046-4049. doi: 10.1128/AAC.00663-13

Kenri, T., Okazaki, N., Yamazaki, T., Narita, M., Izumikawa, K., Matsuoka, M., et al. (2008). Genotyping analysis of Mycoplasma pneumoniae clinical strains in Japan between 1995 and 2005: type shift phenomenon of M. pneumoniae clinical strains. J. Med. Microbiol. 57, 469-475. doi: 10.1099/jmm.0.47634-0

Kenri, T., Seto, S., Horino, A., Sasaki, Y., Sasaki, T., and Miyata, M. (2004). Use of fluorescent-protein tagging to determine the subcellular localization of Mycoplasma pneumoniae proteins encoded by the cytadherence regulatory locus. J. Bacteriol. 186, 6944-6955. doi: 10.1128/JB.186.20.6944-6955.2004

Khanna, M., Fan, J., Pehler-Harrington, K., Waters, C., Douglass, P., Stallock, J., et al. (2005). The pneumoplex assays, a multiplex PCRenzyme hybridization assay that allows simultaneous detection of five organisms, Mycoplasma pneumoniae, Chlamydia (Chlamydophila) pneumoniae, Legionella pneumophila, Legionella micdadei, and Bordetella pertussis, and its real-time counterpart. J. Clin. Microbiol. 43, 565-571. doi: 10.1128/JCM.43.2.565-571.2005

Kita, M., Ohmoto, Y., Hirai, Y., Yamaguchi, N., and Imanishi, J. (1992). Induction of cytokines in human peripheral blood mononuclear cells by mycoplasmas. Microbiol. Immunol. 36, 507-516. doi: 10.1111/j.1348-0421.1992.tb02048.x

Klausner, J. D., Passaro, D., Rosenberg, J., Thacker, W. L., Talkington, D. F., Werner, S. B., et al. (1998). Enhanced control of an outbreak of Mycoplasma pneumoniae pneumonia with azithromycin prophylaxis. J. Infect. Dis. 177, 161-166. doi: $10.1086 / 513818$

Kleemola, M., and Jokinen, C. (1992). Outbreak of Mycoplasma pneumoniae infection among hospital personnel studied by a nucleic acid hybridization test. J. Hosp. Infect. 21, 213-221. doi: 10.1016/0195-6701(92)90078-Z

Kogoj, R., Mrvic, T., Praprotnik, M., and Kese, D. (2015). Prevalence, genotyping and macrolide resistance of Mycoplasma pneumoniae among isolates of patients with respiratory tract infections, Central Slovenia, 2006 to 2014. Euro Surveill. 20:30018. doi: 10.2807/1560-7917.ES.2015.20.37.30018

Kraft, M., Adler, K. B., Ingram, J. L., Crews, A. L., Atkinson, T. P., Cairns, C. B., et al. (2008). Mycoplasma pneumoniae induces airway epithelial cell expression of MUC5AC in asthma. Eur. Respir. J. 31, 43-46. doi: 10.1183/09031936.00103307

Kraft, M., Cassell, G. H., Henson, J. E., Watson, H., Williamson, J., Marmion, B. P., et al. (1998). Detection of Mycoplasma pneumoniae in the airways of adults with chronic asthma. Am. J. Respir. Crit. Care Med. 158, 998-1001. doi: 10.1164/ajrccm.158.3.9711092

Kraft, M., Cassell, G. H., Pak, J., and Martin, R. J. (2002). Mycoplasma pneumoniae and Chlamydia pneumoniae in asthma: effect of clarithromycin. Chest 121, 1782-1788. doi: 10.1378/chest.121.6.1782 
Krause, D. C., and Balish, M. F. (2001). Structure, function, and assembly of the terminal organelle of Mycoplasma pneumoniae. FEMS Microbiol. Lett. 198, 1-7. doi: 10.1111/j.1574-6968.2001.tb10610.x

Krause, D. C., and Balish, M. F. (2004). Cellular engineering in a minimal microbe: structure and assembly of the terminal organelle of Mycoplasma pneumoniae. Mol. Microbiol. 51, 917-924. doi: 10.1046/j.1365-2958.2003.03899.x

Krivan, H. C., Olson, L. D., Barile, M. F., Ginsburg, V., and Roberts, D. D. (1989). Adhesion of Mycoplasma pneumoniae to sulfated glycolipids and inhibition by dextran sulfate. J. Biol. Chem. 264, 9283-9288.

Krueger, K. M., and Barbieri, J. T. (1995). The family of bacterial ADP-ribosylating exotoxins. Clin. Microbiol. Rev 8, 34-47.

Kung, C.-M. (2007). Seroprevalence of Mycoplasma pneumoniae in healthy adolescents in Taiwan. Jpn. J. Infect. Dis. 60, 352-354.

Kunimi, Y., Hirata, Y., Aihara, M., Yamane, Y., and Ikezawa, Z. (2011). Statistical analysis of Stevens-Johnson syndrome caused by Mycoplasma pneumonia infection in Japan. Allergol. Int. 60, 525-532. doi: 10.2332/allergolint.11-OA0309

Lambert, H. P. (1968). Antibody to Mycoplasma pneumoniae in normal subjects and in patients with chronic bronchitis. J. Hyg. (Lond.) 66, 185-189. doi: 10.1017/S0022172400041061

Lee, I., Kim, T. S., and Yoon, H. K. (2006). Mycoplasma pneumoniae pneumonia: CT features in 16 patients. Eur. Radiol. 16, 719-725. doi: 10.1007/s00330-0050026-Z

Lee, S. Y., Lee, Y. H., Chun, B. Y., Lee, S. Y., Cha, S. I., Kim, C. H., et al. (2013). An adult case of Fisher syndrome subsequent to Mycoplasma pneumoniae infection. J. Korean Med. Sci. 28, 152-155. doi: 10.3346/jkms.2013.28.1.152

Leng, Z., Kenny, G. E., and Roberts, M. C. (1994). Evaluation of the detection limits of PCR for identification of Mycoplasma pneumoniae in clinical samples. Mol. Cell. Probes 8, 125-130. doi: 10.1006/mcpr.1994.1017

Lenglet, A., Herrador, Z., Magiorakos, A. P., Leitmeyer, K., Coulombier, D., and European Working Group on Mycoplasma pneumoniae. (2012). Surveillance status and recent data for Mycoplasma pneumoniae infections in the European Union and European Economic Area, January 2012. Euro Surveill. 17:20075.

Linchevski, I., Klement, E., and Nir-Paz, R. (2009). Mycoplasma pneumoniae vaccine protective efficacy and adverse reactions-Systematic review and metaanalysis. Vaccine 27, 2437-2446. doi: 10.1016/j.vaccine.2009.01.135

Lind, K., Benzon, M. W., Jensen, J. S., and Clyde, W. A. Jr. (1997). A seroepidemiological study of Mycoplasma pneumoniae infections in Denmark over the 50-year period 1946-1995. Eur. J. Epidemiol. 13, 581-586. doi: 10.1023/A:1007353121693

Liu, J., Ai, H., Xiong, Y., Li, F., Wen, Z., Liu, W., et al. (2015). Prevalence and correlation of infectious agents in hospitalized children with acute respiratory tract infections in Central China. PLOS ONE 10:e0119170. doi: 10.1371/journal.pone.0119170

Low, I. E. (1971). Effect of medium on $\mathrm{H}_{2} \mathrm{O}_{2}$ levels and peroxidase-like activity by Mycoplasma pneumoniae. Infect. Immun. 3, 80-86.

Luchsinger, V., Ruiz, M., Zunino, E., Martinez, M. A., Machado, C., Piedra, P. A., et al. (2013). Community-acquired pneumonia in Chile: the clinical relevance in the detection of viruses and atypical bacteria. Thorax 68, 1000-1006. doi: 10.1136/thoraxjnl-2013-203551

Maia, I. L., Nicolau, J. C., Machado, M. N., Maia, L. N., Takakura, I. T., Rocha, P. R., et al. (2009). Prevalence of Chlamydia pneumoniae and Mycoplasma pneumoniae in different forms of coronary disease. Arq. Bras. Cardiol. 92, 439-445. doi: 10.1590/S0066-782X2009000600005

Marrie, T. J. (1993). Mycoplasma pneumoniae pneumonia requiring hospitalization, with emphasis on infection in the elderly. Arch. Intern. Med. 153, 488-494. doi: 10.1001/archinte.1993.00410040054008

Marston, B. J., Plouffe, J. F., File, T. M. Jr., Hackman, B. A., Salstrom, S. J., Lipman, H. B., et al. (1997). Incidence of community-acquired pneumonia requiring hospitalization. Results of a population-based active surveillance Study in Ohio. The Community-Based Pneumonia Incidence Study Group. Arch. Intern. Med. 157, 1709-1718. doi: 10.1001/archinte.157.15.1709

Martinez, M. A., Ruiz, M., Zunino, E., Luchsinger, V., and Avendano, L. F. (2008). Detection of Mycoplasma pneumoniae in adult community-acquired pneumonia by PCR and serology. J. Med. Microbiol. 57, 1491-1495. doi: 10.1099/jmm.0.2008/003814-0

Matas, L., Dominguez, J., De Ory, F., Garcia, N., Gali, N., Cardona, P. J., et al. (1998). Evaluation of meridian immuno card mycoplasma test for the detection of Mycoplasma pneumoniae-specific IgM in paediatric patients. Scand. J. Infect. Dis. 30, 289-293. doi: 10.1080/00365549850160954

Matsuoka, M., Narita, M., Okazaki, N., Ohya, H., Yamazaki, T., Ouchi, K., et al. (2004). Characterization and molecular analysis of macrolide-resistant Mycoplasma pneumoniae clinical isolates obtained in Japan. Antimicrob. Agents Chemother. 48, 4624-4630. doi: 10.1128/AAC.48.12.4624-4630.2004

Matute, A. J., Brouwer, W. P., Hak, E., Delgado, E., Alonso, E., and Hoepelman, I. M. (2006). Aetiology and resistance patterns of community-acquired pneumonia in Leon, Nicaragua. Int. J. Antimicrob. Agents 28, 423-427. doi: 10.1016/j.ijantimicag.2006.07.016

Medina, J. L., Coalson, J. J., Brooks, E. G., Winter, V. T., Chaparro, A., Principe, M. F., et al. (2012). Mycoplasma pneumoniae CARDS toxin induces pulmonary eosinophilic and lymphocytic inflammation. Am. J. Respir. Cell Mol. Biol. 46, 815-822. doi: $10.1165 / \mathrm{rcmb} .2011-0135 \mathrm{OC}$

Meng, K. E., and Pfister, R. M. (1980). Intracellular structures of Mycoplasma pneumoniae revealed after membrane removal. J. Bacteriol. 144, 390-399.

Minion, F. C., and Jarvill-Taylor, K. (1994). Membrane-associated hemolysin activities in mycoplasmas. FEMS Microbiol. Lett. 116, 101-106. doi: 10.1111/j.1574-6968.1994.tb06682.x

Miyashita, N., Akaike, H., Teranishi, H., Ouchi, K., and Okimoto, N. (2013). Macrolide-resistant Mycoplasma pneumoniae pneumonia in adolescents and adults: clinical findings, drug susceptibility, and therapeutic efficacy. Antimicrob. Agents Chemother. 57, 5181-5185. doi: 10.1128/AAC.00737-13

Miyashita, N., Kawai, Y., Akaike, H., Ouchi, K., Hayashi, T., Kurihara, T., et al. (2012). Macrolide-resistant Mycoplasma pneumoniae in adolescents with community-acquired pneumonia. BMC Infect. Dis. 12:126. doi: 10.1186/14712334-12-126

Miyashita, N., Kawai, Y., Tanaka, T., Akaike, H., Teranishi, H., Wakabayashi, T., et al. (2015). Diagnostic sensitivity of a rapid antigen test for the detection of Mycoplasma pneumoniae: comparison with real-time PCR. J. Infect. Chemother. 21, 473-475. doi: 10.1016/j.jiac.2015.02.007

Miyashita, N., Kawai, Y., Yamaguchi, T., Ouchi, K., Oka, M., and Study, G. (2011). Clinical potential of diagnostic methods for the rapid diagnosis of Mycoplasma pneumoniae pneumonia in adults. Eur. J. Clin. Microbiol. Infect. Dis. 30, 439-446. doi: 10.1007/s10096-010-1107-8

Miyashita, N., Ouchi, K., Kawasaki, K., Oda, K., Kawai, Y., Shimizu, H., et al. (2008). Mycoplasma pneumoniae pneumonia in the elderly. Med. Sci. Monit. 14, CR387-CR391.

Miyashita, N., Sugiu, T., Kawai, Y., Oda, K., Yamaguchi, T., Ouchi, K., et al. (2009). Radiographic features of Mycoplasma pneumoniae pneumonia: differential diagnosis and performance timing. BMC Med Imaging 9:7. doi: 10.1186/14712342-9-7

Miyata, M., and Ogaki, H. (2006). Cytoskeleton of mollicutes. J. Mol. Microbiol. Biotechnol. 11, 256-264. doi: 10.1159/000094059

Mogabgab, W. J. (1968). Mycoplasma pneumoniae and adenovirus respiratory illnesses in military and university personnel, 1959-1966. Am. Rev. Respir. Dis. $97,345-358$.

Mok, J. Y., Waugh, P. R., and Simpson, H. (1979). Mycoplasma pneumonia infection. A follow-up study of 50 children with respiratory illness. Arch. Dis. Child 54, 506-511. doi: 10.1136/adc.54.7.506

Moore, C., Perry, M., and Cottrell, S. (2014). The emerging role of community sentinel surveillance in the understanding of the clinical features and epidemiology of acute Mycoplasma pneumoniae infection. Clin. Microbiol. Infect. 20, O489-O492. doi: 10.1111/1469-0691.12499

Morrison-Plummer, J., Lazzell, A., and Baseman, J. B. (1987). Shared epitopes between Mycoplasma pneumoniae major adhesin protein P1 and a 140kilodalton protein of Mycoplasma genitalium. Infect. Immun. 55, 49-56.

Moule, J. H., Caul, E. O., and Wreghitt, T. G. (1987). The specific IgM response to Mycoplasma pneumoniae infection: interpretation and application to early diagnosis. Epidemiol. Infect. 99, 685-692. doi: 10.1017/S0950268800066541

Mufson, M. A., Manko, M. A., Kingston, J. R., and Chanock, R. M. (1961). Eaton agent pneumonia-clinical features. JAMA 178, 369-374. doi: 10.1001/jama.1961.03040430005002

Mustafa, M. I., Al-Marzooq, F., How, S. H., Kuan, Y. C., and Ng, T. H. (2011). The use of multiplex real-time PCR improves the detection of the bacterial etiology of community acquired pneumonia. Trop Biomed 28, 531-544.

Nagalingam, N. A., Adesiyun, A. A., Swanston, W. H., and Bartholomew, M. (2004). Prevalence of Mycoplasma pneumoniae and Chlamydia pneumoniae in 
pneumonia patients in four major hospitals in Trinidad. New Microbiol. 27, 345-351.

Nakane, D., Kenri, T., Matsuo, L., and Miyata, M. (2015). Systematic structural analyses of attachment organelle in Mycoplasma pneumoniae. PLoS Pathog. 11:e1005299. doi: 10.1371/journal.ppat.1005299

Nambu, A., Saito, A., Araki, T., Ozawa, K., Hiejima, Y., Akao, M., et al. (2006). Chlamydia pneumoniae: comparison with findings of Mycoplasma pneumoniae and Streptococcus pneumoniae at thin-section CT. Radiology 238, 330-338. doi: 10.1148/radiol.2381040088

Neocleous, C., Gerogianni, I., Gourgoulianis, K., and Petinaki, E. (2014). Prevalence of atypical bacterial pathogens in hospitalised adult patients with community-acquired pneumonia in Central Greece. Indian J. Med. Microbiol. 32, 204-205. doi: 10.4103/0255-0857.129852

Niederman, M. S. (2001). Guidelines for the management of community-acquired pneumonia. Current recommendations and antibiotic selection issues. Med. Clin. North Am. 85, 1493-1509.

Nilsson, A. C., Bjorkman, P., and Persson, K. (2008). Polymerase chain reaction is superior to serology for the diagnosis of acute Mycoplasma pneumoniae infection and reveals a high rate of persistent infection. BMC Microbiol 8:93. doi: 10.1186/1471-2180-8-93

Nir-Paz, R., Abutbul, A., Moses, A. E., Block, C., and Hidalgo-Grass, C. (2012). Ongoing epidemic of Mycoplasma pneumoniae infection in Jerusalem, Israel, 2010 to 2012. Euro Surveill. 17:20095.

Nir-Paz, R., Michael-Gayego, A., Ron, M., and Block, C. (2006). Evaluation of eight commercial tests for Mycoplasma pneumoniae antibodies in the absence of acute infection. Clin. Microbiol. Infect. 12, 685-688. doi: 10.1111/j.14690691.2006.01469.x

Nisar, N., Guleria, R., Kumar, S., Chand Chawla, T., and Ranjan Biswas, N. (2007). Mycoplasma pneumoniae and its role in asthma. Postgrad. Med. J. 83, 100-104. doi: 10.1136/pgmj.2006.049023

Norisue, Y., Tokuda, Y., Koizumi, M., Kishaba, T., and Miyagi, S. (2008). Phasic characteristics of inspiratory crackles of bacterial and atypical pneumonia. Postgrad. Med. J. 84, 432-436. doi: 10.1136/pgmj.2007.067389

Obeidat, N., Qatouseh, L., and Shehabi, A. (2005). Rare occurrence of Mycoplasma pneumoniae infection among Jordanian adults with respiratory tract infections. Microbial Ecology in Health and Disease 17, 216-218. doi: $10.1080 / 08910600600600232$

Okazaki, N., Narita, M., Yamada, S., Izumikawa, K., Umetsu, M., Kenri, T., et al. (2001). Characteristics of macrolide-resistant Mycoplasma pneumoniae strains isolated from patients and induced with erythromycin in vitro. Microbiol. Immunol. 45, 617-620. doi: 10.1111/j.1348-0421.2001.tb01293.x

Onozuka, D., and Chaves, L. F. (2014). Climate variability and nonstationary dynamics of Mycoplasma pneumoniae pneumonia in Japan. PLoS ONE 9:e95447. doi: 10.1371/journal.pone.0095447

Parisi, A., and Filice, G. (2001). Transverse myelitis associated with Mycoplasma pneumoniae pneumonitis: a report of two cases. Infez. Med. 9, 39-42.

Pereyre, S., Charron, A., Hidalgo-Grass, C., Touati, A., Moses, A. E., Nir-Paz, R., et al. (2012). The spread of Mycoplasma pneumoniae is polyclonal in both an endemic setting in France and in an epidemic setting in Israel. PLoS ONE 7:e38585. doi: 10.1371/journal.pone.0038585

Pereyre, S., Touati, A., Petitjean-Lecherbonnier, J., Charron, A., Vabret, A., and Bebear, C. (2013). The increased incidence of Mycoplasma pneumoniae in France in 2011 was polyclonal, mainly involving M. pneumoniae type 1 strains. Clin. Microbiol. Infect. 19, E212-E217. doi: 10.1111/1469-0691.12107

Perez, C., and Artola, V. (2001). Adult Still's disease associated with Mycoplasma pneumoniae infection. Clin. Infect. Dis. 32, E105-E106. doi: 10.1086/319342

Perez, C., Mendoza, H., Hernandez, R., Valcayo, A., and Guarch, R. (1997). Leukocytoclastic vasculitis and polyarthritis associated with Mycoplasma pneumoniae infection. Clin. Infect. Dis. 25, 154-155. doi: 10.1086/516888

Petitjean, J., Vabret, A., Gouarin, S., and Freymuth, F. (2002). Evaluation of four commercial immunoglobulin $\mathrm{G}$ (IgG)- and IgM-specific enzyme immunoassays for diagnosis of Mycoplasma pneumoniae infections. J. Clin. Microbiol. 40, 165-171. doi: 10.1128/JCM.40.1.165-171. 2002

Petitjean Lecherbonnier, J., Vabret, A., Gouarin, S., Dina, J., Legrand, L., and Freymuth, F. (2006). Infections à Mycoplasma pneumoniae : étude rétrospective en Basse-Normandie de 1997 à 2005. Pathol. Biol. 54, 603-611.
Petrone, B. L., Wolff, B. J., DeLaney, A. A., Diaz, M. H., and Winchell, J. M. (2015). Isothermal detection of Mycoplasma pneumoniae directly from respiratory clinical specimens. J. Clin. Microbiol. 53, 2970-2976. doi: 10.1128/JCM. 01431-15

Pitcher, D., Chalker, V. J., Sheppard, C., George, R. C., and Harrison, T. G. (2006). Real-time detection of Mycoplasma pneumoniae in respiratory samples with an internal processing control. J. Med. Microbiol. 55, 149-155. doi: 10.1099/jmm.0.46281-0

Polkowska, A., Harjunpaa, A., Toikkanen, S., Lappalainen, M., Vuento, R., Vuorinen, T., et al. (2012). Increased incidence of Mycoplasma pneumoniae infection in Finland, 2010-2011. Euro Surveill. 17:20072.

Ponka, A., Ponka, T., Sarna, S., and Penttinen, K. (1981). Questionable specificity of lipid antigen in the Mycoplasma pneumoniae complement fixation test in patients with extrapulmonary manifestations. J. Infect. 3, 332-338. doi: 10.1016/S0163-4453(81)91901-0

Porath, A., Schlaeffer, F., and Lieberman, D. (1997). The epidemiology of community-acquired pneumonia among hospitalized adults. J. Infect. 34, 4148. doi: 10.1016/S0163-4453(97)80008-4

Prodromidou, S. K., Pape, M., Anagnostou, V., Mandraveli-Chatzikosta, K., Dionysopoulou, S., and Diza, E. (2010). Seasonality of Mycoplasma pneumoniae, Chlamydia pneumoniae, respiratory syncytial virus and adenovirus paediatric respiratory tract infections in northern Greece - A 2-year study [poster]. Clin. Microbiol. Infect. 16:S429.

Putman, C. E., Curtis, A. M., Simeone, J. F., and Jensen, P. (1975). Mycoplasma pneumonia. Clinical and roentgenographic patterns. Am. J. Roentgenol. Radium. Ther. Nucl. Med. 124, 417-422. doi: 10.2214/ajr.124.3.417

Razin, S., and Jacobs, E. (1992). Mycoplasma adhesion. J. Gen. Microbiol. 138, 407-422. doi: 10.1099/00221287-138-3-407

Razin, S., Yogev, D., and Naot, Y. (1998). Molecular biology and pathogenicity of mycoplasmas. Microbiol. Mol. Biol. Rev. 62, 1094-1156.

Reittner, P., Muller, N. L., Heyneman, L., Johkoh, T., Park, J. S., Lee, K. S., et al. (2000). Mycoplasma pneumoniae pneumonia: radiographic and highresolution CT features in 28 patients. AJR Am. J. Roentgenol. 174, 37-41. doi: 10.2214/ajr.174.1.1740037

Roberts, D. D., Olson, L. D., Barile, M. F., Ginsburg, V., and Krivan, H. C. (1989). Sialic acid-dependent adhesion of Mycoplasma pneumoniae to purified glycoproteins. J. Biol. Chem. 264, 9289-9293.

Rollins, S., Colby, T., and Clayton, F. (1986). Open lung biopsy in Mycoplasma pneumoniae pneumonia. Arch. Pathol. Lab. Med. 110, 34-41.

Rottem, S. (2003). Interaction of mycoplasmas with host cells. Physiol. Rev. 83, 417-432. doi: 10.1152/physrev.00030.2002

Saito, R., Misawa, Y., Moriya, K., Koike, K., Ubukata, K., and Okamura, N. (2005). Development and evaluation of a loop-mediated isothermal amplification assay for rapid detection of Mycoplasma pneumoniae. J. Med. Microbiol. 54, 10371041. doi: 10.1099/jmm.0.46071-0

Saraya, T., Kurai, D., Nakagaki, K., Sasaki, Y., Niwa, S., Tsukagoshi, H., et al. (2014). Novel aspects on the pathogenesis of Mycoplasma pneumoniae pneumonia and therapeutic implications. Front. Microbiol. 5:410. doi: 10.3389/fmicb.2014.00410

Saraya, T., Nakata, K., Nakagaki, K., Motoi, N., Iihara, K., Fujioka, Y., et al. (2011). Identification of a mechanism for lung inflammation caused by Mycoplasma pneumoniae using a novel mouse model. Results Immunol. 1, 76-87. doi: 10.1016/j.rinim.2011.11.001

Schurwanz, N., Jacobs, E., and Dumke, R. (2009). Strategy to create chimeric proteins derived from functional adhesin regions of Mycoplasma pneumoniae for vaccine development. Infect. Immun 77, 5007-5015. doi: 10.1128/IAI. 00268-09

Schwartz, S. B., Thurman, K. A., Mitchell, S. L., Wolff, B. J., and Winchell, J. M. (2009). Genotyping of Mycoplasma pneumoniae isolates using real-time PCR and high-resolution melt analysis. Clin. Microbiol. Infect 15, 756-762. doi: 10.1111/j.1469-0691.2009.02814.x

Seto, S., Kenri, T., Tomiyama, T., and Miyata, M. (2005). Involvement of P1 adhesin in gliding motility of Mycoplasma pneumoniae as revealed by the inhibitory effects of antibody under optimized gliding conditions. J. Bacteriol. 187, 1875-1877. doi: 10.1128/JB.187.5.1875-1877.2005

Seto, S., and Miyata, M. (2003). Attachment organelle formation represented by localization of cytadherence proteins and formation of the electron-dense core 
in wild-type and mutant strains of Mycoplasma pneumoniae. J. Bacteriol. 185, 1082-1091. doi: 10.1128/JB.185.3.1082-1091.2003

Seybert, A., Herrmann, R., and Frangakis, A. S. (2006). Structural analysis of Mycoplasma pneumoniae by cryo-electron tomography. J. Struct. Biol. 156, 342-354. doi: 10.1016/j.jsb.2006.04.010

Shangguan, Z., Sun, Q., Zhang, M., Ding, J., Yi, L., Gao, Y., et al. (2014). Mycoplasma pneumoniae infection in hospitalized adult patients with community-acquired pneumonia in China. J. Infect. Dev. Ctries 8, 1259-1266. doi: $10.3855 /$ jidc. 4721

Shankar, E. M., Kumarasamy, N., Balakrishnan, P., Solomon, S., Lejith, R., Vengatesan, A., et al. (2006). Serosurveillance of acute Mycoplasma pneumoniae infection among HIV infected patients with pulmonary complaints in Chennai. Southern India. J. Infect. 53, 325-330. doi: 10.1016/j.jinf.2005.11.184

Shimizu, M., Hamaguchi, Y., Matsushita, T., Sakakibara, Y., and Yachie, A. (2012). Sequentially appearing erythema nodosum, erythema multiforme and HenochSchonlein purpura in a patient with Mycoplasma pneumoniae infection: a case report. J. Med. Case Rep. 6:398. doi: 10.1186/1752-1947-6-398

Shimizu, T., Kimura, Y., Kida, Y., Kuwano, K., Tachibana, M., Hashino, M., et al. (2014). Cytadherence of Mycoplasma pneumoniae induces inflammatory responses through autophagy and toll-like receptor 4. Infect. Immun. 82, 30763086. doi: 10.1128/IAI.01961-14

Simecka, J. W., Ross, S. E., Cassell, G. H., and Davis, J. K. (1993). Interactions of mycoplasmas with B cells: antibody production and nonspecific effects. Clin. Infect. Dis. 17(Suppl. 1), S176-S182. doi: 10.1093/clinids/17.Supplement_1.S176

Smith-Norowitz, T. A., Silverberg, J. I., Kusonruksa, M., Weaver, D., Ginsburg, D., Norowitz, K. B., et al. (2013). Asthmatic children have increased specific anti-Mycoplasma pneumoniae IgM but not IgG or IgE-values independent of history of respiratory tract infection. Pediatr. Infect. Dis. J. 32, 599-603. doi: 10.1097/INF.0b013e3182862ea8

Somer, A., Salman, N., Yalcin, I., and Agacfidan, A. (2006). Role of Mycoplasma pneumoniae and Chlamydia pneumoniae in children with communityacquired pneumonia in Istanbul, Turkey. J. Trop. Pediatr. 52, 173-178. doi: 10.1093/tropej/fml017

Somerson, N. L., Walls, B. E., and Chanock, R. M. (1965). Hemolysin of Mycoplasma pneumoniae: tentative identification as a peroxide. Science 150, 226-228. doi: 10.1126/science.150.3693.226

Song, J. H., Thamlikitkul, V., and Hsueh, P. R. (2011). Clinical and economic burden of community-acquired pneumonia amongst adults in the Asia-Pacific region. Int. J. Antimicrob. Agents 38, 108-117. doi: 10.1016/j.ijantimicag.2011.02.017

Spuesens, E. B., Meijer, A., Bierschenk, D., Hoogenboezem, T., Donker, G. A., Hartwig, N. G., et al. (2012). Macrolide resistance determination and molecular typing of Mycoplasma pneumoniae in respiratory specimens collected between 1997 and 2008 in the Netherlands. J. Clin. Microbiol. 50, 1999-2004. doi: 10.1128/JCM.00400-12

Su, C. J., Chavoya, A., Dallo, S. F., and Baseman, J. B. (1990). Sequence divergency of the cytadhesin gene of Mycoplasma pneumoniae. Infect. Immun. 58, 26692674.

Suhs, R. H., and Feldman, H. A. (1966). Serologic epidemiologic studies with M. pneumoniae. II. Prevalence of antibodies in several populations. Am. J. Epidemiol. 83, 357-365.

Sutherland, E. R., Brandorff, J. M., and Martin, R. J. (2004). Atypical bacterial pneumonia and asthma risk. J. Asthma 41, 863-868. doi: 10.1081/JAS200038477

Suzuki, S., Yamazaki, T., Narita, M., Okazaki, N., Suzuki, I., Andoh, T., et al. (2006). Clinical evaluation of macrolide-resistant Mycoplasma pneumoniae. Antimicrob. Agents Chemother. 50, 709-712. doi: 10.1128/AAC.50.2.709712.2006

Szczepanek, S. M., Majumder, S., Sheppard, E. S., Liao, X., Rood, D., Tulman, E. R., et al. (2012). Vaccination of BALB/c mice with an avirulent Mycoplasma pneumoniae $\mathrm{P} 30$ mutant results in disease exacerbation upon challenge with a virulent strain. Infect. Immun. 80, 1007-1014. doi: 10.1128/IAI.06078-11

Tagliabue, C., Salvatore, C. M., Techasaensiri, C., Mejias, A., Torres, J. P., Katz, K., et al. (2008). The impact of steroids given with macrolide therapy on experimental Mycoplasma pneumoniae respiratory infection. J. Infect. Dis. 198, 1180-1188. doi: $10.1086 / 591915$
Takahashi, T., Morozumi, M., Okada, T., Chiba, N., Asami, R., Murayama, S. Y., et al. (2009). Prolonged Mycoplasma pneumoniae infection in an elderly patient with community-acquired pneumonia. J. Infect. Chemother. 15, 243-247. doi: 10.1007/s10156-009-0692-x

Talkington, D. F., Shott, S., Fallon, M. T., Schwartz, S. B., and Thacker, W. L. (2004). Analysis of eight commercial enzyme immunoassay tests for detection of antibodies to Mycoplasma pneumoniae in human serum. Clin. Diagn. Lab. Immunol. 11, 862-867. doi: 10.1128/CDLI.11.5.862-867.2004

Tamaoki, J. (2004). The effects of macrolides on inflammatory cells. Chest 125, 41S-50S. doi: 10.1378/chest.125.2_suppl.41S

Tanaka, H., Koba, H., Honma, S., Sugaya, F., and Abe, S. (1996). Relationships between radiological pattern and cell-mediated immune response in Mycoplasma pneumoniae pneumonia. Eur. Respir. J. 9, 669-672. doi: $10.1183 / 09031936.96 .09040669$

Tani, K., Shimizu, T., Kida, Y., and Kuwano, K. (2011). Mycoplasma pneumoniae infection induces a neutrophil-derived antimicrobial peptide, cathelin-related antimicrobial peptide. Microbiol. Immunol. 55, 582-588. doi: 10.1111/j.13480421.2011.00353.x

Techasaensiri, C., Tagliabue, C., Cagle, M., Iranpour, P., Katz, K., Kannan, T. R., et al. (2010). Variation in colonization, ADP-ribosylating and vacuolating cytotoxin, and pulmonary disease severity among Mycoplasma pneumoniae strains. Am. J. Respir. Crit. Care Med. 182, 797-804. doi: 10.1164/rccm.201001$0080 \mathrm{OC}$

Tjhie, J. H., Savelkoul, P. H., and Vandenbroucke-Grauls, C. M. (1997). Polymerase chain reaction evaluation for Mycoplasma pneumoniae. J. Infect. Dis. 176, 1124-1125. doi: 10.1086/516535

Touati, A., Pereyre, S., Bouziri, A., Achour, W., Khaldi, A., Ben Jaballah, N. et al. (2010). Prevalence of Mycoplasma pneumoniae-associated respiratory tract infections in hospitalized children: results of a 4-year prospective study in Tunis. Diagn. Microbiol. Infect. Dis. 68, 103-109. doi: 10.1016/j.diagmicrobio.2010.05.010

Trachtenberg, S. (1998). Mollicutes-wall-less bacteria with internal cytoskeletons. J. Struct. Biol. 124, 244-256. doi: 10.1006/jsbi.1998.4063

Tryon, V. V., and Baseman, J. B. (1987). The acquisition of human lactoferrin by Mycoplasma pneumoniae. Microb. Pathog. 3, 437-443. doi: 10.1016/08824010(87)90013-1

Tsiodras, S., Kelesidis, I., Kelesidis, T., Stamboulis, E., and Giamarellou, H. (2005). Central nervous system manifestations of Mycoplasma pneumoniae infections. J. Infect. 51, 343-354. doi: 10.1016/j.jinf.2005.07.005

Uldum, S. A., Bangsborg, J. M., Gahrn-Hansen, B., Ljung, R., Molvadgaard, M., Fons Petersen, R., et al. (2012). Epidemic of Mycoplasma pneumoniae infection in Denmark, 2010 and 2011. Euro Surveill. 17:20073.

Uldum, S. A., Jensen, J. S., Sondergard-Andersen, J., and Lind, K. (1992). Enzyme immunoassay for detection of immunoglobulin $\mathrm{M}$ ( $\operatorname{IgM}$ ) and $\operatorname{IgG}$ antibodies to Mycoplasma pneumoniae. J. Clin. Microbiol. 30, 1198-1204.

Vanaja, S. K., Rathinam, V. A., and Fitzgerald, K. A. (2015). Mechanisms of inflammasome activation: recent advances and novel insights. Trends Cell Biol. 25, 308-315. doi: 10.1016/j.tcb.2014.12.009

Vikerfors, T., Brodin, G., Grandien, M., Hirschberg, L., Krook, A., and Pettersson, C. A. (1988). Detection of specific IgM antibodies for the diagnosis of Mycoplasma pneumoniae infections: a clinical evaluation. Scand. J. Infect. Dis. 20, 601-610. doi: 10.3109/00365548809035660

von Baum, H., Welte, T., Marre, R., Suttorp, N., Luck, C., and Ewig, S. (2009). Mycoplasma pneumoniae pneumonia revisited within the German Competence Network for Community-acquired pneumonia (CAPNETZ). BMC Infect. Dis. 9:62. doi: 10.1186/1471-2334-9-62

Wadowsky, R. M., Castilla, E. A., Laus, S., Kozy, A., Atchison, R. W., Kingsley, L. A., et al. (2002). Evaluation of Chlamydia pneumoniae and Mycoplasma pneumoniae as etiologic agents of persistent cough in adolescents and adults. J. Clin. Microbiol. 40, 637-640. doi: 10.1128/JCM.40.2.637-640.2002

Waites, K. B., and Talkington, D. F. (2004). Mycoplasma pneumoniae and its role as a human pathogen. Clin. Microbiol. Rev. 17, 697-728. doi: 10.1128/CMR.17.4.697-728.2004

Waldo, R. H. III, and Krause, D. C. (2006). Synthesis, stability, and function of cytadhesin $\mathrm{P} 1$ and accessory protein $\mathrm{B} / \mathrm{C}$ complex of Mycoplasma pneumoniae. J. Bacteriol. 188, 569-575. doi: 10.1128/JB.188.2.569-575.2006 
Walicka, M., Majsterek, M., Rakowska, A., Slowinska, M., Sicinska, J., Goralska, B., et al. (2008). Mycoplasma pneumoniae-induced pneumonia with StevensJohnson syndrome of acute atypical course. Pol. Arch. Med. Wewn 118, 449-453.

Waller, J. L., Diaz, M. H., Petrone, B. L., Benitez, A. J., Wolff, B. J., Edison, L., et al. (2014). Detection and characterization of Mycoplasma pneumoniae during an outbreak of respiratory illness at a university. J. Clin. Microbiol. 52, 849-853. doi: 10.1128/JCM.02810-13

Walter, N. D., Grant, G. B., Bandy, U., Alexander, N. E., Winchell, J. M., Jordan, H. T., et al. (2008). Community outbreak of Mycoplasma pneumoniae infection: school-based cluster of neurologic disease associated with household transmission of respiratory illness. J. Infect. Dis. 198, 1365-1374. doi: $10.1086 / 592281$

Wang, K., Chalker, V., Bermingham, A., Harrison, T., Mant, D., and Harnden, A. (2011). Mycoplasma pneumoniae and respiratory virus infections in children with persistent cough in England: a retrospective analysis. Pediatr. Infect. Dis. J. 30, 1047-1051. doi: 10.1097/INF.0b013e31822db5e2

Watkins, R. R., and Lemonovich, T. L. (2011). Diagnosis and management of community-acquired pneumonia in adults. Am. Fam. Phys. 83, 1299-1306.

Watkins-Riedel, T., Stanek, G., and Daxboeck, F. (2001). Comparison of SeroMP IgA with four other commercial assays for serodiagnosis of Mycoplasma pneumoniae pneumonia. Diagn. Microbiol. Infect. Dis. 40, 21-25. doi: 10.1016/S0732-8893(01)00250-4

Watson, M. E. Jr., and Storch, G. A. (2008). Recurrent Mycoplasma pneumoniae infection in a human immunodeficiency virus-positive child. Pediatr. Infect. Dis. J. 27, 1037-1038. doi: 10.1097/INF.0b013e318178276b

Wattanathum, A., Chaoprasong, C., Nunthapisud, P., Chantaratchada, S., Limpairojn, N., Jatakanon, A., et al. (2003). Community-acquired pneumonia in southeast Asia: the microbial differences between ambulatory and hospitalized patients. Chest 123, 1512-1519. doi: 10.1378/chest.123. 5.1512

Wellinghausen, N. W., Baetz, O., Kramer, J., and Boettcher, M. (2012). Was winter 2010/11 a Mycoplasma pneumoniae epidemic season in Germany? [poster]. Clin. Microbiol. Infect. 18, 134-135.

Wilson, M. H., and Collier, A. M. (1976). Ultrastructural study of Mycoplasma pneumoniae in organ culture. J. Bacteriol. 125, 332-339.

Winchell, J. M., Thurman, K. A., Mitchell, S. L., Thacker, W. L., and Fields, B. S. (2008). Evaluation of three real-time PCR assays for detection of Mycoplasma pneumoniae in an outbreak investigation. J. Clin. Microbiol. 46, 3116-3118. doi: 10.1128/JCM.00440-08

Wood, P. R., Hill, V. L., Burks, M. L., Peters, J. I., Singh, H., Kannan, T. R., et al. (2013). Mycoplasma pneumoniae in children with acute and refractory asthma. Ann. Allergy Asthma Immunol. 110:e321. doi: 10.1016/j.anai.2013.01.022

Wu, H. M., Wong, K. S., Huang, Y. C., Lai, S. H., Tsao, K. C., Lin, Y. J., et al. (2013). Macrolide-resistant Mycoplasma pneumoniae in children in Taiwan. J. Infect. Chemother. 19, 782-786. doi: 10.1007/s10156-0120523-3

Xiang, M., and Fan, J. (2010). Pattern recognition receptor-dependent mechanisms of acute lung injury. Mol. Med. 16, 69-82. doi: 10.2119/molmed.2009.00097

Yamazaki, T., Kuroki, H., Itagaki, T., Iwata, S., and Tateda, K. (2015). Evaluation of a rapid antigen detection kit targeting L7/L12 ribosomal protein for Mycoplasma pneumoniae. Kansenshogaku Zasshi 89, 394-399.

Yang, J., Hooper, W. C., Phillips, D. J., and Talkington, D. F. (2002). Regulation of proinflammatory cytokines in human lung epithelial cells infected with Mycoplasma pneumoniae. Infect. Immun. 70, 3649-3655. doi: 10.1128/IAI.70.7.3649-3655.2002

Yang, J., Hooper, W. C., Phillips, D. J., and Talkington, D. F. (2003). Interleukin1beta responses to Mycoplasma pneumoniae infection are cell-type specific. Microb. Pathog. 34, 17-25. doi: 10.1016/S0882-4010(02)00190-0

Yang, J., Hooper, W. C., Phillips, D. J., and Talkington, D. F. (2004). Cytokines in Mycoplasma pneumoniae infections. Cytokine Growth. Factor. Rev. 15, 157-168. doi: 10.1016/j.cytogfr.2004.01.001

Yano, T., Ichikawa, Y., Komatu, S., Arai, S., and Oizumi, K. (1994). Association of Mycoplasma pneumoniae antigen with initial onset of bronchial asthma. Am. J. Respir. Crit. Care Med. 149, 1348-1353. doi: 10.1164/ajrccm.149.5.8173777

Yavlovich, A., Tarshis, M., and Rottem, S. (2004). Internalization and intracellular survival of Mycoplasma pneumoniae by non-phagocytic cells. FEMS Microbiol. Lett. 233, 241-246. doi: 10.1016/j.femsle.2004. 02.016

Yoshino, M., Annaka, T., Kojima, T., and Ikedo, M. (2008). Sensitive and rapid detection of Mycoplasma pneumoniae by loop-mediated isothermal amplification. Kansenshogaku Zasshi 82, 168-176. doi: 10.11150/kansenshogakuzasshi1970.82.168

Zhang, L., Zong, Z. Y., Liu, Y. B., Ye, H., and Lv, X. J. (2011). PCR versus serology for diagnosing Mycoplasma pneumoniae infection: a systematic review \& meta-analysis. Indian J. Med. Res. 134, 270-280.

Zhao, H., Li, S., Cao, L., Yuan, Y., Xue, G., Feng, Y., et al. (2014). Surveillance of Mycoplasma pneumoniae infection among children in Beijing from 2007 to 2012. Chin. Med. J. (Engl.) 127, 1244-1248.

Conflict of Interest Statement: The authors declare that the research was conducted in the absence of any commercial or financial relationships that could be construed as a potential conflict of interest.

Copyright (c) 2016 Parrott, Kinjo and Fujita. This is an open-access article distributed under the terms of the Creative Commons Attribution License (CC BY). The use, distribution or reproduction in other forums is permitted, provided the original author(s) or licensor are credited and that the original publication in this journal is cited, in accordance with accepted academic practice. No use, distribution or reproduction is permitted which does not comply with these terms. 